THE UNIVERSITY OF

WARWICK

\begin{tabular}{||c||}
\hline Feb 2016 \\
Spanish Agriculture in the Little Divergence \\
Carlos Álvarez-Nogal, Leandro Prados de la Escosura \\
and Carlos Santiago-Caballero \\
\\
\hline
\end{tabular}

WORKING PAPER SERIES

Centre for Competitive Advantage in the Global Economy

Department of Economics 


\title{
Spanish Agriculture in the Little Divergence ${ }^{12}$
}

\author{
Carlos Álvarez-Nogal (Universidad Carlos III), \\ Leandro Prados de la Escosura (Universidad Carlos III, CEPR, and CAGE), \\ Carlos Santiago-Caballero (Universidad Carlos III)
}

\begin{abstract}
This paper explores the role of agriculture in Spain's contribution to the little divergence in Europe. On the basis of tithes, long-run trends in agricultural output are drawn. After a long period of relative stability, output suffered a severe contraction during 1570-1620, followed by stagnation to 1650, and steady expansion thereafter. Output per head shifted from a relatively high to a low path that persisted until the nineteenth century. The decline in agricultural output per head and per worker from a relatively high level contributed to Spain falling behind and, hence, to the Little Divergence in Europe. Output per worker moved along labour force in agriculture over the long run, supporting the depiction of Spain as a frontier economy. Institutional factors, in a context of financial and monetary instability and war, along climatic anomalies, provide explanatory hypotheses that deserve further research.
\end{abstract}

Keywords: agriculture, tithes, early modern Spain, labour productivity, little divergence

JEL Classification: N53, 013, Q10

\author{
Carlos Álvarez-Nogal, \\ canogal@clio.uc3m.es \\ Leandro Prados de la Escosura, \\ leandro.prados.delaescosura@uc3m.es \\ and Carlos Santiago-Caballero \\ carlos.santiago@uc3m.es \\ Departamento de Ciencias Sociales, \\ Universidad Carlos III, \\ 28903 Getafe (Madrid), Spain
}

\footnotetext{
1 To Gonzalo Anes and Ángel García Sanz, in memoriam.

${ }^{2}$ We acknowledge comments by Steve Broadberry, Bruce Campbell, Patrick O’Brien, Blanca SánchezAlonso, and participants at the HEDG/CAGE/CEPR Workshop on Recent Developments in Historical National Accounting, University of Southern Denmark, Odense, April 2015; the European Historical Economics Society Conference, Pisa, September 2015; and the Economic and Social History Seminar, Nuffield College, Oxford, February 2016. Fernando S. Rodrigo kindly provided us with rainfall data for Andalusia. Bas van Leeuwen and Paolo Malanima shared their data and provided us with some clarifications. David Reher kindly allowed us to use his unpublished baptism regional estimates and Enrique Llopis Agelán gave us detailed explanations about the construction of his own baptism series at regional level. Research assistance by Juana Lamote de Grignon, Alberto Murcia, and Teresa Prados de la Escosura is greatly appreciated. Our research has been supported by Spain's Ministerio de Economía y Competitividad Grant ECO2012-38028.
} 


\section{Introduction}

In recent years, quantitative research has shed new light on the economic performance of early modern Spain that shows a decline relative to Western Europe (Yun-Casalilla, 1994; Carreras, 2003; Álvarez-Nogal and Prados de la Escosura, 2007, 2013). Comparative history also suggests that Spain (along Italy) fell behind from an initial advantage position, while Britain and the Netherlands forged ahead, contributing to the little divergence and the reversal of fortune in Europe (Broadberry, 2013). Sir John Elliott's old plea, "'to compare Spanish conditions with those of other contemporary societies" (Elliot, 1961: 55) would have, thus, been answered. Why Spain fell behind remains, however, elusive. Explanations are highly speculative, including recent ones that stress the insecurity of property rights and the impact of absolutism on trade and colonial institutions in a context of extractive institutions (Acemoglu and Robinson, 2012: 218-222), and the institutional fragmentation, that would have hindered market integration (Grafe, 2012). Beyond the issue of how accurate these grand interpretations are, a precise description of the factors and mechanism that drove Spain's falling behind is needed. Public finance, trade and credit, urban activities, and agricultural performance need to be quantified and their interconnections established before an overall assessment can be provided. Only then would it be possible, as Elliott suggested, isolating any features unique to Spain.

"The conditions of the soil and the nature of land-holding" (Elliott, 1961: 56) captured historians' attention during the late twentieth century. Economic historians of early modern Spain have used indirect information on religious taxes -the tithe, in particular- to derive trends in output. Studies of main crops' output, most of them dating from the 1970s and early 1980s, are abundant. Although regional agricultural output has occasionally been computed, monographs were mainly carried out at local or provincial level. ${ }^{3}$ The daunting effort required to unifying and analysing dozens of studies for different products in different regions and at different periods of time may

\footnotetext{
${ }^{3}$ See footnote 11 below. At the 2008 conference of the Spanish economic association aggregate estimates of agricultural output on the basis of tithes were presented for some regions.
} 
have discouraged historians from attempting to provide a wider spatial picture. ${ }^{4}$ The only attempt at assessing the evolution of agricultural output in Spain on the basis tithe series was made by Gonzalo Anes and Ángel García Sanz (1982) in an overview grounded on Ricardo's theory of differential rent (Ricardo, 1817, 1951). They argued that, during the sixteenth and eighteenth centuries, foodstuffs' relative prices rose in response to increasing urban demand -a consequence of demographic expansion-, leading to an expansion of land under the plough, at the expense of pasture and forest. Yields per seed and per hectare declined, as less fertile land was cultivated and technological change was mainly absent. As a result, land rent increased and labour productivity and real wages fell. Conversely, during the seventeenth century, as population stagnated and urban demand contracted, relative prices for foodstuffs fell and marginal lands were reverted to pasture and forest. Yields, wages, and labour productivity recovered while land rents declined. Anes and García Sanz nuanced their interpretation by emphasising regional disparities in agricultural performance during the early modern era.

More recently, indirect estimates of Spain's regional and national output have been derived using a demand function approach (Álvarez-Nogal and Prados de la Escosura, 2007, 2013) in which agricultural consumption per head is estimated and, times population, absolute consumption derived. ${ }^{5}$ Then, after adjustment for net food imports, absolute output is obtained.

The main results obtained from the demand approach for early modern Spain suggest that output per head, after peaking prior to the Black Death (1348), declined from mid-fifteenth to mid-seventeenth century -although its level remained high until

${ }^{4}$ Difficulties to interpreting the information provided by archival records on tithes have also led historians to avoid using data not collected directly by themselves.

${ }^{5}$ Real consumption per head of agricultural goods $(\boldsymbol{C})$ can be expressed as

$$
C=a P^{\varepsilon} Y^{\mu} M^{\nu} \quad[1]
$$

In which $P$ and $M$ denote agricultural, and non-agricultural prices relative to the consumer price index, respectively; $Y$ stands for real disposable income per head; $\varepsilon, \mu$, and $\gamma$ are the values of own price, income and cross price elasticities, respectively; and $a$ represents a constant. 
the 1550s- and, then, stabilized at a low level, before another episode of decline took place in the second half of the eighteenth century (Álvarez-Nogal and Prados de la Escosura, 2013).

These findings may be considered, to some extent, explicit conjectures as they are based upon limited empirical evidence on real wage rates and land rents -used as proxies for disposable income per head-, and hypothetical values for income- and own price elasticities. ${ }^{6}$ However, the results are robust to alternative specifications using different proxies for real disposable income per head and elasticities values. ${ }^{7}$

Constructing direct estimates of aggregate output seems so far unfeasible. Thus, information on tithes provides an alternative procedure to derive output measures that, although also indirect, arguably require less stringent assumptions than those involved in the demand approach. ${ }^{8}$ Thus, it is our purpose to provide, on the basis of tithes, estimates of agricultural output in early modern Spain that will be compared to the results from the demand approach.

Grain was, by far, the most important component of agricultural output in late medieval and early modern Spain, and although it lost ground in some regions (coastal areas, in particular), it still kept its predominance in agriculture by 1800 , amounting to nearly half the value of agricultural output in the 1790s (Polo y Catalina, 1803). Continuous series for grain tithes can be traced back to the early fifteenth century in Old Castile or Andalusia, for many regions in the sixteenth century, and for practically all of them from the seventeenth to the early nineteenth century. However, it is generally accepted that the reliability of tithes as a proxy for agricultural output decreased significantly after the Napoleonic invasion, so we set 1800 as the end year

\footnotetext{
${ }^{6}$ This approach has been criticised on the grounds that by using wage rates as a proxy for disposable income a considerable margin of error can be introduced in the estimates (Llopis Agelán and González Mariscal, 2010).

${ }^{7}$ See detailed discussion of alternative proxies for real disposable income per head, including the shortcomings of real wage rates, in in medieval and early modern Spain in Álvarez-Nogal and Prados de la Escosura (2013: 4-9).

${ }^{8}$ This is historians' usual assumption. See, for example, Llopis Agelán and González Mariscal (2010: 15).
} 
for our estimates. In addition to cereal, tithes for major agricultural crops: wine and olive oil but also legumes, fruit, and animal produce are available for the main producing regions from 1500 onwards.

Our main findings can be summarized as follows. On the basis of tithes it can be shown that agricultural output was at a high level over 1500-1570. Then, a decline took place in two phases, a sharp but short one in the 1570 s and 1580 s, followed by a milder and steady one to the 1610s. After a period of stagnation, recovery followed from the mid-seventeenth to the mid-eighteenth century, when the highest levels of the early modern era were achieved. Then, after a sharp contraction in the 1760 s, moderate expansion took place at along a lower path during the late eighteenth century.

Our decadal estimates of agricultural output per head reinforce the view of a dramatic discontinuity in the last decades of the sixteenth century, in which agriculture shifted from a high path a low one that prevailed until the nineteenth century.

Trends in agricultural output per economically active population show long run decline in Spain (as was also the case in Italy) in contrast with its rise in Britain and Holland. Thus, the comparison between Spain (and Italy) and North-Western Europe (Britain and Holland) highlights the role played by agriculture in the Little Divergence within Europe, as well as a reversal of fortune, since from an advantageous position Mediterranean countries fell behind during the early modern era.

Moreover, output per worker and labour force in agriculture evolved alongside over the long run, expanding up to 1570 , declining to mid-seventeenth century, and recovering steadily thereafter, which suggests the depiction of Spain as a frontier economy. Therefore, as an alternative to the usual neo-Malthusian explanation, we hypothesise that the impact of financial policies in an environment of monetary instability and war, together with climatic anomalies, explains the collapse in agricultural out per head and per worker between the late sixteenth and the early seventeenth centuries and its slow recovery, as incentives to allocate land and labour to agricultural production diminished. 


\section{Tithes as a Proxy for Agricultural Production}

Tithes have been traditionally considered a major tax in the pre-industrial era, particularly during the Middle Ages when most of the European population lived on agriculture and centralized fiscal systems had not been developed (Pöschl, 1927). The tithe was an ecclesiastical tax, imposed on all farming production including the incomes obtained from livestock. Nominally, the tithe represented 10 per cent of total production but, in practice, its share fluctuated and usually remained below this percentage. In Mediterranean Europe the most important products taxed were grains (wheat, barley, oats and rye), wine, and olive oil.

Tithe records can be traced back in time to the High Middle Ages but the survival of written sources reduces the time span in which they are available. Although wars and epidemics made difficult their collection, in Roman Catholic countries the tithes did not vanish or disappear altogether until the French Revolution and the Napoleonic Wars, providing continuous series for several centuries. However, researchers did not exploit the abundance of tithe records in most of Europe until the twentieth century. Earlier studies focused on explaining the existence of the tithe, the methods used for its collection, or the tax legislation (Viard, 1909-14; Borah, 1941; Boyd, 1952). It was only since the 1960s when a quantitative approach was adopted for the study of tithes with the main objective of reconstructing fiscal time series that would capture the long run evolution of agricultural output.

The new methodology introduced by the Annales School, allowed to exploit the potential of tithes to analyse economic and social change in early modern France, as well as shedding light on other economic and social variables (prices, yields, productivity, types of cultivation, living standards) (Goubert, 1960; Baehrel, 1961). Labrousse (1962) initiated a systematic analysis of agricultural production in preindustrial France using the tithes as the main source that was soon extended to regional studies (Le Roy Ladurie, 1966; Morineau, 1970; Deyon, 1967; Le Roy Ladurie and Goy, 1972). Tithe series collection became a collective effort that in 1969 materialised in a publication including more than 20 studies at local level. Together with France, the volume also included regions such as Andalusia (Spain) and Sicily (Italy). Later, in 1977, Goy and Le Roy Ladurie hosted an international conference on 
tithes with the participation of more than 60 historians from 17 countries. The new studies allowed the extension of the available data set in both chronological (from the fourteenth to the nineteenth centuries) and geographical terms (Europe and Latin America) (Goy and Le Roy Ladurie, 1982). The wide geographical coverage of tithes opened the debate about the homogeneity of the data and the possibility of carrying out comparative studies. Difficulties concerning the direct conversion between tithes and agrarian output, as collection methods changed over time and varied across regions; the resistance of peasants to pay the tax; the way tithes were collected (directly or rented out to private agents) and paid (in kind or cash), were main issues in the debate. ${ }^{9}$

The impulse given to tithes in France (Neveux, 1980; Bois, 1984; Derville, 1987), also encouraged the research in other countries in Europe: Belgium (Ruwet, 1964), Spain (Cabo Alonso, 1955; Anes and Le Flem, 1965; Anes, 1970; Ponsot, 1986), Hungary (Kirilly and Kiss, 1968), and Latin America (Borah, 1949). More recently, research on tithes has extended to Sweden (Leijonhufvud, 2001; Olsson and Sevensson, 2010) and England (Evans, 1976; Kain, 1979; Dodds, 2004, 2007). ${ }^{10}$

Thanks to the abundance of records kept in ecclesiastical and national archives Spain is, perhaps, the country in which research on tithes has been as widespread as in France. In addition to the wealth of the archival records, it is worth stressing that the information provided by tithes is the same for all Spanish regions and kingdoms regardless their different fiscal systems. After the research effort carried out in the 1970s and 1980s, and still going on, a wide sample of tithe records at local is available for most regions. ${ }^{11}$ However, an aggregate view of agricultural performance at national

\footnotetext{
${ }^{9}$ See the discussion in Goy and Le Roy Ladurie (1982) and Le Roy Ladurie and Goy (1982).

${ }^{10}$ Due to the abundance of alternative sources such as manors' accounting records, tithes have been largely neglected in England. This fact may also reflect the inferior quality of English tithe returns (we owe this remark to Bruce Campbell).

${ }^{11}$ Including Andalusia (Granada, Garzón Pareja, 1974, 1982; Malaga, Benítez Sánchez-Blanco, 1982; Seville, Ladero Quesada, 1979; Ponsot, 1986), Extremadura (Pereira Iglesias, 1990; Llopis Agelán, 1979), Murcia (Lemeneunier, 1982), New Castile (Toledo, López-Salazar, Pérez and Martín Galán, 1981), Old Castile-Leon (Segovia, García Sanz, 1982; Leon, Sebastián Amarilla, 1992; Zamora, Álvarez Vázquez,
} 
level on the basis of tithes is, with the exception of the early attempt by Anes and García Sanz (1982), still missing.

How reliable are tithes as a proxy for agricultural output has been widely debated. As with all taxes, producers could hide part of the harvest depending on the degree of coercion and enforcement. In fact, due to its fiscal nature, tithes have been questioned as they may bias output downwards. Tithe evasion could vary overtime. As the production diversified, the opportunities for evasion increased. Tithes covered main products and new crops (i.e., maize, potatoes) could escape them in the early years of cultivation. Although tithes were collected in kind, occasionally they were paid in cash, so deflation is required to draw trends in output. Also, in some instances, institutions leased tithe collection to private agents who bid for the right to collect them, so records do not reflect actual production but the value of the winning bid. In such cases, deflation is also required. Lastly, depending on several circumstances, some producers were partially or totally exempt from paying the tithe in specific years (i.e., Excusado).

Nonetheless, the way in which the collection of the tithes was carried out prevented most of these problems. The calculation of the tithe took place in the same fields, before each producer was even able to move the production. The collector was a local agent and his salary was connected to the total amount collected. The tithe was estimated from the harvest, before any amount could be subtracted for seeding or to pay rents (Melón Jiménez, 1987). If the local knowledge and incentives of the collector to guarantee a fair taxation was not enough, the local priest that received part of the tithe also acted as a supervisor. In order to avoid cheating, the priest read in public the names and the amounts paid by each producer, and the rest could express their objections if they found any irregularity (Santiago-Caballero, 2011). These mechanisms guaranteed that the amounts paid were correct, at least until the institutional turmoil caused by the Napoleonic invasion in the nineteenth century made the collection of

1984), Basque Country (Bilbao and Fernández de Pinedo, 1982), Galicia (Eiras Roel, 1982), Aragon (Latorre Cria, 2007), Balearics (Mallorca, Vidal, 1978), Catalonia (Badosa, 1978; Fradera, 1978), and Valencia (Ardit Lucas, 1989, and Palop Ramos, 1982). 
the tithe more complicated. There were also incentives on the side of the producer in order to pay the tithes. In the absence of land registries, the payment of the tithes also worked as an informal institution to guarantee property rights on the lands that they owned or rented, and therefore its payment was also a guarantee of those rights (Santiago-Caballero, 2014).

Furthermore, in Spain, tithe receipts were divided into three components: one, accruing to the bishop; another, to the local priest; and a third one, divided between the king and the parish. The diversity of beneficiaries multiplied the accounting records available allowing a direct comparison between different sources. The tazmía books, for instance, that recorded the amounts that were paid by each peasant, were kept in each parish. The data from this source can be compared to the records that were kept in private, ecclesiastical, or national archives.

Tithes are, thus, considered to represent roughly a fixed proportion of total production (García Sanz, 1979) and to provide reliable output trends over the long run, constituting a unique source for the study of agriculture's performance in early modern Spain. This situation was only broken by the French invasion in 1808 when the social and political turmoil facilitated peasants' passive resistance to pay the tithe (Anes and García Sanz, 1982).

\section{Method}

Unlike most Spanish studies that use a regional and, often, a local approach, in this paper a national perspective has been chosen. Thus, aggregates for main crops have been constructed on the basis of an extensive dataset of tithe series at regional and local levels. Converting a wide array of a heterogeneous series into a set of relatively homogeneous and comparable series across space has been a painstaking and time-consuming process. We have been able to gather tithe records from as early as the fourteenth century. However, given the sketchy nature of the early records and 
the difficulty to link them to later series, our agricultural output estimates only cover from 1500 onwards. ${ }^{12}$

The choice of a procedure to aggregate multiple series into homogenous and continuous series was a key decision. One of the available choices at our disposal was the utilization of econometric techniques such as panel data regression or principal components analysis that could have help us to derive standardised series (Clark, 2002). However, we considered that an advanced statistical manipulation of the original series would imply loosing important information about local trends that would be diluted into the aggregate figures while rendering the resulting series useless for econometric treatment. When the sources made it possible, our favoured approach was working on the series at a local level. The first step was establishing whether the series were complete on an annual basis. In most of the cases we found gaps in the records that ranged from just one year to longer periods of time. The way in which we dealt with missing values depended on the amount of information lost and on the availability of sources. When the number of missing observations was small, we derived them by extrapolating the results from series in the same region that presented a similar behaviour due to analogous climatic and soil conditions. In order to obtain the best estimation, we used as proxy the series that were geographically close to the one to be estimated. Missing years were interpolated using the available series that showed a higher correlation in the years around the missing values. ${ }^{13}$ In our

\footnotetext{
12 Given the lack of consistent data no adjustment has been made for crops partially or totally exempt from paying the tithe (i.e., "Excusado" and "diezmos privativos") as it would have required applying an arbitrary correction. Moreover, until 1761, "Excusado" was collected through a distribution of a yearly lump-sum payment among bishops and other ecclesiastical institutions, and such distribution was estimated using tithes.

${ }^{13}$ When we found missing values, we interpolated them using other tithe series in the same region that presented a high correlation with the incomplete one. However, our experience shows that series that presented high correlations in the very long run do not have to necessarily have high correlations in the short term. For that reason we estimated the correlation of the incomplete series with the complete ones around the missing years and not for the whole sample. For instance, if for the same region we had several series between 1500 and 1800 but one of them had missing values between 1550-1555, we
} 
opinion, when the amount of years to be estimated was manageable, this procedure offers the most reliable way to filling the gaps in the series and provides the best possible estimations.

When the amount of missing values was larger or the existence of alternative local series more scarce, we had to rely on alternative methods. In these cases, we filled the missing values using the average weight that the local series to be estimated did represent in the aggregate provincial sample. ${ }^{14}$ However, we were aware of the fact that the weights of the series within the sample changed over time and, therefore, that we had to make adjustments to calculate missing years in the same location that were separated by long periods of time. For that reason we decided to re-calculate the weight of the municipality around each gap. The periods used to estimate the weights therefore varied within the same municipality depending on the years that had to be estimated, a fact that adds robustness to our estimation. Once we had estimated the missing years for all the local series, we simply aggregated them in order to generate the provincial series. When we counted on local series from different authors for the same province and period, we used the overlapping periods in order to splice them and derive a single series. We also followed the same process in those cases in which the series came from the same source but different local series were available for different periods of time, and we spliced them through on the basis of the overlapping years.

As a result of a long and detailed process we derived series at provincial or regional level that were, then, combined in order to obtain national aggregates for the main crops: cereals, wine, olive oil, legumes, fruit, and animal produce (including wool and silk). Unfortunately, except for cereals, no complete data exist at regional level, so there is no enough information to provide regional estimates of agricultural output.

proxied those missing values using the most similar series in the region around that period (1530-1580 for example) and not for the whole 300 years.

${ }^{14}$ For example, if we had a study with ten local series and the one with the missing years represented a 20 per cent of the total production, we used that percentage to estimate the gaps from the information contained in the other nine. 
It is for cereals for which the availability of data is wider over space and time with different series covering Andalusia (three out of four provinces, Seville -which included also Cadiz and Huelva-, Cordoba, and Granada, which included Malaga), Extremadura, Murcia, New Castile, Old Castile-Leon (including Burgos -which also included Rioja and Santander-, Leon -which included Asturias-, Palencia, Segovia, Soria, Valladolid, and Zamora), Galicia, Basque Provinces, and the Canaries, within the Kingdom of Castile; plus Aragon, Balearics, Catalonia, and Valencia, in the Kingdom of Aragon; plus the Kingdom of Navarre. As in the case of individual series, we had to interpolate missing values with the help of geographically close series. We then constructed regional series by assuming that series for missing provinces evolve alongside those for which data were available. ${ }^{15}$ Alternatively, missing values for odd years were log-linearly interpolated.

As for wine, tithes information was restricted to Andalusia (Cadiz, Huelva, Seville, and Cordoba), Old Castile (Rioja, since 1550, and Segovia, since 1610), Basque (since 1537), Navarre (since 1568), Aragon, and Catalonia (since 1670). ${ }^{16}$ These regions represented, nonetheless, the main producing areas.

In the case of olive oil information only related to Andalusia (Seville and Cordoba, since 1581), Extremadura (since 1697), Balearics (1716-69) and Catalonia (1750-1800). Again, these were the main producers in early modern Spain.

\footnotetext{
${ }^{15}$ Thus, Cordoba pre-1580 series were assumed to evolve alongside those for Seville's. In the case of East Andalusia, series for Malaga were used, completed for missing years with those for Granada (17901800). In the case of Burgos, the series for 1402-1519 were spliced with those for 1590 onwards with the available series for Rioja that was largely part of the Burgos province before the 1833 reform. The Burgos series were considered representative for Old Castile before 1520. Segovia, 1550-70, assuming its evolution was similar to that of Valladolid and Palencia; 1523-50, along Zamora; pre-1523, Burgos. Series for Zamora were assumed to represent the evolution of the series for Segovia, León, and over 1523-1550. For Navarre, we completed the series by assuming it moved along the Basque Provinces since 1639.

${ }^{16}$ Rioja was assumed to evolve as Aragon during the years 1502-1550. Navarre was assumed to evolve along Rioja from 1626 onwards.
} 
Information about tithes on legumes and fruit is scant and we only managed to get tithes for Balearics and Catalonia from 1649 onwards, and for Valencia since 1499. ${ }^{17}$ These areas represent, nonetheless, more than one-third of the value of production in the 1799 Census.

In the case of animal produce, tithes are available for Old Castile (Segovia and Soria), Extremadura, Murcia, Aragon, and Valencia. ${ }^{18}$

How to weight provincial series for each crop poses a major challenge. The 1799 Census of Fruits and Manufactures provides the only available estimate of quantities and values of agricultural and industrial goods for early modern Spain. It has a poor reputation largely due to Josep Fontana's (1967) severe critique. Nonetheless, Fontana largely exonerated cereal production from his criticism and suggested a correction for olive oil output. Unfortunately there is no alternative to the 1799 Census. A possibility would be to derive weights from the highly reputed Cadastre of Ensenada for the 1750s, but only covers the Kingdom of Castile, leaving aside the Kingdom of Aragon (including Aragon, Balearics, Catalonia, and Valencia) and the Kingdom of Navarre. Furthermore, no distinction is made in the Cadastre's "respuestas generales" (aggregate results) by crops, only between crops and animal produce (Matilla Tascón, 1947; Grupo '75, 1977).

We re-computed the value of total output for the 1799 benchmark by, firstly, correcting olive oil production, as suggested by Fontana; then, valuing each crop at a single price derived as the weighted average of provincial prices. Using a single set of prices helps to correct for the risk of spurious provincial prices (also pointed out by Fontana), while provides us with consistent estimates. Furthermore, it implies a purchasing power parity adjustment across Spanish provinces. The value of agricultural

\footnotetext{
${ }^{17}$ Catalonia was assumed to evolve as Balearics after 1771. In the case of Valencia, fruits index was backwards projected with vegetables index for 1500-1552.

${ }^{18}$ In the case of Old Castile, tithes were taken from Segovia (wool), 1573-1800 and Soria (lamb), 16811800. In the case of Extremadura, tithes on cattle and sheep were used from 1692 onwards. For Murcia, tithes on wool were used for 1650-1800. Tithes for Aragon (lamb) covered from 1610 onwards. Tithes for Valencia (livestock) covered the entire period, 1500-1800.
} 
output c. 1799 resulted from aggregating the value of each crop obtained by multiplying its quantity by its average national price.

We, then, used provincial (regional) shares in the value of each main crop in 1799 as weights to construct national volume indices for each of them, expressed using $1790 / 99$ as 100 .

Trends in main crops' output are presented in Table 1 and Figure 1. It can be observed that their tendencies are highly coincidental, although a closer look shows distinctive behaviour among different crops. Output appears to have grown across the board up to the early 1570s. The expansion of wine production appears remarkable during the first two-thirds of the sixteenth century remaining at high output levels until 1590. The increase in the output of wine, a high-income elastic good, is consistent with the progress experienced by the Spanish economy. This depiction also fits olive oil, a more volatile product. Most crops fell, then, to 1620, although olive oil reached a trough in the 1580s and expanded thereafter, while cereals and wine reached their trough later in the 1630 s and 1640 s, respectively. The recovery and expansion of animal produce and legumes and fruits provided an offsetting element to main crops' contraction over 1620-1650. Between mid-seventeenth and mid-eighteenth centuries all crops expanded, although it was initially sluggish in the cases of cereals and olive oil. The behaviour of fruits and legumes conveys -with some reservation due to tithes' poor coverage- the view of products whose demand was raising over time, as contracted less intensively between mid-sixteenth and early seventeenth century and grew above average thereafter. Animal produce experienced stronger expansion between early seventeenth and mid-eighteenth century, in which the increasing weight of stabled (estante) livestock throughout the eighteenth century, relative to the transhumant livestock, may have played a role (Phillips and Phillips, 1997). From mideighteenth century, after the 1760s contraction, output growth decelerated across the board, with the exception of olive oil, until 1800.

The valuation of livestock output in the 1799 Census raises a problem as the stock of livestock (number of different type of cattle) is mixed up with animal produce (i.e., wool). Therefore, the total value of animal output should be reduced, in principle, to offset its over-exaggeration. However, livestock figures are grossly underestimated 
in the 1799 Census, as a comparison with those of the 1750s Cadastre of Ensenada for the Kingdom of Castile -which roughly double the figures for the Castilian provinces-, suggests (García Sanz, 1985, 1994). Since there is no evidence of a major catastrophe in Castilian livestock during the second half of the eighteenth century, such discrepancy evidences a downward bias in the 1799 Census. It is worth noting that the share of animal produce in agricultural output was 29 per cent in 1910 (Prados de la Escosura, 2003: 50). Given the expansion of crops, largely at the expense of livestock, throughout the nineteenth century, a share of 31 per cent for animal produce in 1799 does seem reasonable, so we have accepted it. ${ }^{19}$

We, then, need to construct an index of agricultural output over time. An option would be weighting the quantity index for each crop by its share in 1799 agricultural output. However, estimating aggregate output with fixed 1799 weights over three centuries introduces a serious index number problem, since relative prices change over time and, consequently, the fixed late-eighteenth century weights become less representative as one moves away from the benchmark year.

A superior alternative is constructing a Divisia index of agricultural output. Thus, we have computed an index of agricultural output by weighting yearly variations in each crop's output by the average, at adjacent years, of the shares of each crop in agriculture output at current prices and, then, obtaining its exponential. That is,

$$
\ln Q_{t}-\ln Q_{t-1}=\Sigma_{i}\left[\theta_{Q i t}\left(\ln Q_{i t}-\ln Q_{i t-1}\right)\right]
$$

Where share values are computed as:

$$
\left.\theta_{\text {Qit }}=1 / 2\left[\theta_{i t}+\theta_{\text {it- } 1}\right)\right]
$$

Current values, $V$, for each crop $i$ at year $t$ were obtained by projecting the value of each crop in $1799, V_{i 1799}$, backwards with the quantity index built on the basis of tithes, $Q$, and a price index expressed in silver grams, $P$ (expressed as $1790 / 99=1$ ) and, then, by adding them up the total value of agricultural output, $\mathrm{V}_{\mathrm{j}}$, was derived.

\footnotetext{
${ }^{19}$ Agricultural historians coincide in pointing to a decline in livestock output simultaneous to a rise in crops output over the late 19th century. See GEHR (1978/79).
} 


$$
\mathrm{V}_{\mathrm{t}}=\Sigma \mathrm{V}_{\mathrm{it}}=\Sigma \mathrm{V}_{\mathrm{i} 1799} * \mathrm{Q}_{\mathrm{it}} * \mathrm{P}_{\mathrm{ijt}}
$$

Later, the share of each crop, $V_{i t} / V_{t}$, was obtained.

Prices used for each main crop come from Felíu (1991), for Catalonia, and from Hamilton (1934, 1947, and Hamilton's unpublished manuscript working sheets kindly provided by Robert Allen) for Andalusia, New and Old Castile, and Valencia, and have been weighted by the regional shares in each main crop's production in order to derive prices at national level. The share of each major crop in agriculture output at current prices is presented at decadal averages in Figure 2. It can be observed that cereal and animal produce are the main contributors to agricultural output and show opposite trends, with animal produce increasing its share in the seventeenth century and cereals' share declining, and recovery of cereals' share at the expense of animal produce's from 1730 onwards.

As a sensitivity test, we also computed agricultural output assuming a lower share for animal produce in total output. The share adopted, 19.8 per cent, corresponds to agricultural value added in the Kingdom of Castile in the 1750s, and derives from the Cadastre of Ensenada (Grupo '75, 1977: 177). ${ }^{20}$ We can observe that by accepting a lower share for animal produce the level of agricultural output is raised up to 1660 , implying a slight deceleration over time, but no significant alteration of its long run trend (Figure 3 and Table 2). ${ }^{21}$

\section{Agricultural output and population}

Agricultural output shows mild long run growth over 1500-1800 that can be divided into distinctive phases (Figure 4). The first one was of sustained expansion that accelerated since the 1530 s and peaked in the early 1570 s (Table 2). A contraction occurred between the 1570s and the 1610s, -more intensively until 1590-, followed by three decades of stagnation. Steady long run expansion took place from mid-

\footnotetext{
${ }^{20}$ In 1799, the share of animal produce in agricultural output for the kingdom of Castile was practically identical to that for Spain as a whole.

${ }^{21}$ The alternative estimates of agricultural output, obtained with the lower bound share for animal produce, are presented at decadal intervals in Appendix A, Table A-1.
} 
seventeenth century, only broken during the War of Succession (1701-1715), and peaked in the 1750s, when the highest output level in four centuries was achieved. Then, after intense contraction in the 1760s, output growth resumed but slowed down until the end of the century.

Regional variance resulting from differences in factor endowments, trade opportunities, and institutional change has been considered to be far from negligible (Anes and García Sanz, 1982). Lack of comprehensive data precludes a breakdown of agricultural output at regional level. Main crops' evolution may capture regional tendencies. For example, the evolution of cereal output in five macro-regions (North, interior, Mediterranean, Andalusia, and the Canaries) can be attempted (Figure 5). ${ }^{22}$ However, It is worth stressing that differences in regional specialization render cereals trends unrepresentative of those in aggregate agricultural output.

The sustained expansion to 1570 was led by Andalusia, and the Mediterranean region (Valencia, in particular) plus New Castile (whose contribution is concealed by opposite trends in other regions of the Interior). In the long decline across the board from 1570 to mid-seventeenth century, Andalusia and the Mediterranean (particularly, Catalonia) experienced a sharper contraction during its early phase, 1570-1590, while the Interior (New Castile and, especially, Old Castile), drove the fall in output between 1590 and 1620, and was, again, the Mediterranean (especially Catalonia) and New Castile the regions which suffered the deepest contraction in the first half of the seventeenth century, while the Canaries expanded. Later, during the sustained expansion from the mid-seventeenth century, only broken in the 1710s and 1760s, the Mediterranean region played a leading role, being the only region that exhibited strong growth in the second half of the seventeenth century and the fastest one in the countrywide growth during eighteenth century.

Thus, while Andalusia and New Castile, along with the Mediterranean, drove the sixteenth century expansion, the main driver of cereal output growth since the

\footnotetext{
${ }^{22}$ North includes Asturias, Galicia, Basque Country, and Navarre; Interior incorporates Extremadura, New and Old Castile, and Aragon; Mediterranean, in turn, Murcia, Valencia, Catalonia, and Balearic Islands. Unfortunately incomplete data does not allow us to provide a more detailed regional breakdown.
} 
mid-seventeenth century was the Mediterranean region. It can, thus, be suggested that, to the extent cereals capture long run trends in aggregate agricultural output, a process of divergence emerges between the interior and the Mediterranean periphery since the late seventeenth century.

How do production trends compare to those of population? Annual population series are lacking and all we have are benchmark estimates from vecindarios (neighbourhoods, literally, but, actually, population surveys for taxation purposes), up to 1700 , and national censuses in the late eighteenth century (Pérez Moreda, 1988). As an alternative, historians have relied on baptism records to draw population trends (Nadal, 1988; Reher, personal communication; Llopis, 2004). This procedure implies strong assumptions: deaths rates kept a stable relationship with birth rates and net migration flows were negligible over time. ${ }^{23}$ Since these are highly unrealistic, we have built a compromise population figures by reconciling benchmark estimates with baptism decadal series. ${ }^{24}$ Thus, the resulting estimates relax the astringent assumptions implicit in simply using baptism series, capturing, hence, migration (either forced or voluntary) and variations in the ratio between birth and death rates.

\footnotetext{
${ }^{23}$ The number of Moorish expelled from Spain (1609-1613) could have reached up to 300,000, according to Domínguez Ortiz and Vincent (1993), a figure also accepted by Pérez Moreda (1988: 380). As regards voluntary migration, flows to Spanish America has been estimated in 250,000 and 100,000 in the 16th and 17th centuries, respectively, and about 120,000 over 1700-1824 (Martínez Shaw, 1994: $152,167)$.

${ }^{24}$ Except in the pioneer work by Nadal (1984), who provided annual figures, regional and national baptism indices are presented as decadal averages, so we have been unable to provide annual estimates of agricultural output per head.
} 
In order to derive a compromise estimate of total population, we have projected each benchmark estimate with decadal baptism series back and forth. ${ }^{25}$ Since the projected benchmark level with baptism indices does not match the adjacent benchmark estimate, to obtain single estimates a variable-weighted geometric average has been computed for each pair of estimates derived using adjacent benchmarks, in which the closest benchmark series gets a larger weight. Thus,

$$
N_{t}=\left(X_{t}\right)^{(n-t) / n} *\left(Y_{t}\right)^{t / n} \quad \text { for } 0 \leq t \leq T
$$

Being $N_{t}$ the new population decadal estimates, $X_{t}$ and $Y_{t}$, the values corresponding to the projection of adjacent benchmark figures, $X$ and $Y$ (i.e., 1700 and 1750) with baptism decadal indices, respectively; and $n$ the number of years in between 0 and $T$.

The resulting compromise population decadal estimates -that should be considered largely conjectural, especially, prior to 1700- are presented in Figure 6. Over the three centuries considered, population grew at an annual compound rate of 0.3 per cent. In the sixteenth century fast demographic expansion took place, at a yearly rate of 0.5 per cent over $1500-1590$, accelerating to 0.9 percent during the 1530-1570. Then, population declined until 1640 (at -0.2 per cent) and remained stagnant during the central decades of the seventeenth century. Thus, by the 1650s the size of Spanish population was probably 10 per cent smaller than in the 1580s. From 1660 onwards, but for a reversal in the 1710s and occasional stagnation periods, population expanded at moderate pace until 1800 (at nearly 0.4 per cent annually).

\section{Trends in agricultural output per person and worker}

Trends in agricultural output per person can, now, be drawn (Figure 7). Longterm stability at high level of output per head is the main feature of a first phase that

\footnotetext{
${ }^{25}$ For 1610s-1790s we have used Llopis Agelán and Sebastián Amarilla (2007) baptism decadal series and their partial coverage series up to the 1580s, completed with Reher's own partial estimates for 1520s-1580s (personal communication). As for the pre-1520s decades, we had to rely on log-linear interpolation of benchmark estimates. Benchmark figures for 1420, 1530, 1591, 1700, 1750, 1787, and 1797 come from Nadal (1984), Carreras (2003), Bustelo (1972a,b), Nicolau (2005) and Pérez Moreda (1988, 1999).
} 
lasted to 1570 . A sharp decline took place between the 1560 s and 1610 s, with output per person shrinking to 70 per cent of its initial level, which intensified between 1570 and 1590 (Table 3). A steady expansion at moderate pace took place between 1620 and 1760, punctuated by occasional reversals (particularly in the 1690s). After another severe contraction in the 1760 s, growth resumed until the end of the century at a similar pace. On the whole, by the end of the eighteenth century, agricultural output per person would have shrunk to three-fourths of its level at the beginning of the sixteenth century. Two main features of the evolution of agricultural output per head can be highlighted. On the one hand, the dramatic decline between the late sixteenth and early seventeenth century shifted agricultural output per person to a lower level from which it would not recover until the nineteenth century. On the other, during expansion periods (1520s-1560s, 1610s-1750s, and 1760s-1790s) growth proceeded at a similar pace but along successively lower paths as a result of contraction episodes.

How do the new estimates compare to those derived through the demand approach? A major difference between the two sets of estimates is that while, in the demand approach, consumption per head is directly computed, in the case of the tithe-based estimate output per head results are very sensitive to the population estimates used. ${ }^{26}$ Tithe-based and demand approach estimates provide roughly the same trends for agricultural output per head (Table 3 and Figure 7). The shift from a high to a low path of output per head is found in both estimates, although a more gradual and longer decline is observed in the demand approach estimates that reached a trough in the 1640 s and exhibited a stronger but shorter life recovery to the 1720s. Furthermore, the demand approach estimates points to a sustained decline during the second half of the eighteenth century.

A further and more challenging step is estimating output per worker in agriculture. Labour productivity levels in early modern agriculture should be ideally measured in terms of output per day or hour worked as peasants often performed

\footnotetext{
${ }^{26}$ A shortcoming of the estimates for the case of Spain is net imports of foodstuffs were assumed to be negligible, so consumption and output per head were considered equivalent (Álvarez-Nogal and Prados de la Escosura, 2013).
} 
other occupations outside agriculture during the slack session and the number of days worked may have varied over time (Álvarez-Nogal and Prados de la Escosura, 2013). Unfortunately, as regards the labour input, all that can be crudely estimated so far is economically active population in agriculture $\left(\operatorname{EAP}_{\mathrm{AG}}\right)$, which has been obtained in three stages. Firstly, working age population (WAP) estimates were derived by projecting the share of working age population in total population (WAP/N) in 1797 (0.578, according to Pérez Moreda, 1982a) backwards to 1586 on the basis of shares in total population of those aged 16-50 for New Castile (NC) (derived from Reher, 1991) and assuming that the late sixteenth century WAP share was acceptable for the entire century, and, then, multiplying the resulting WAP/N times total population (N).

$$
W_{A P}=(W A P / N)_{1797}\left(W_{t} P_{N C} / N_{N C}\right) N_{t}
$$

Later, the economically active population/ working age population ratio (EAP/WAP) for males in 1797, estimated at 0.916 by Pérez Moreda (1982a), was applied to the resulting working age population (WAP) series to derive the economically active population figures (EAP). ${ }^{27}$

$$
\mathrm{EAP}_{\mathrm{t}}=(\mathrm{EAP} / \mathrm{WAP})_{1797} \mathrm{WAP}_{\mathrm{t}}
$$

Unfortunately, we only have data on the share of agriculture in male EAP $\left(\mathrm{EAP}_{\mathrm{AG}} / \mathrm{EAP}\right.$ ) for 1797 (0.652) (Pérez Moreda, 1999). Thus, following Wrigley (1985) and Allen (2000) we arbitrarily assumed a fixed 80 per cent share of EAP in agriculture as the starting point in 1500 and interpolated log-linearly the shares between 1500 and $1797 .^{28}$ Then, to derive EAP in agriculture $\left(E_{A P}\right)$ we applied the share of agriculture in total EAP to total EAP estimates.

\footnotetext{
${ }^{27}$ The available information on economically active population in the 1797 census refers mostly to males (Pérez Moreda, 1982b). The EAP/WAP share for males and females would be lower. However, since we are applying a fixed ratio over time, that of 1797 (expression 8) and we, then, construct an index of EAP in agriculture, the exaggeration in the 1797 EAP level does not have any impact on our labour productivity estimates.

${ }^{28}$ The share of EAP in agriculture in regions of the Kingdom of Castile is systematically higher in the Godoy censuses (1797) than in the Cadastre de Ensenada (1752). We have opted for the former as it
} 


$$
\mathrm{EAP}_{\mathrm{AGt}}=\left(\mathrm{EAP}_{\mathrm{AG}} / \mathrm{EAP}\right)_{\mathrm{t}} \mathrm{EAP}_{\mathrm{t}}
$$

The resulting estimates are highly conjectural as we assume fixed 1797 WAP/N and EAP/WAP ratios and the share of agriculture in the labour force is log-linearly interpolated but, nonetheless, they provide orders of magnitude. However, the main objection does not derive from the estimate of the number of those economically active in agriculture but from our inability to estimating the amount of work per EAP (days, hours) over time which results no only from the seasonality of agriculture but from the peasants' incentives to allocate their effort to agricultural activities (Simpson, 1992; Álvarez-Nogal and Prados de la Escosura, 2013).

Output per EAP evolved largely in parallel with output per head, which could be partly due to the crude assumptions in the computation of agricultural labour force (Figure 8 and Table 4). Nonetheless, it is worth highlighting that after the collapse over 1570-1620, while output per head recovered since the 1620s, output per EAP only started its recovery in the 1650 s but experienced a more intense growth thereafter, especially in the second half of the seventeenth century.

As a sensitivity test we estimated labour productivity after re-computing $E_{A P}$ by keeping a fixed share of EAP in agriculture (0.66). Output per worker does not alter its trend even though it suffers a slight deceleration over time (Table 4//5).

How does the experience of Spanish agriculture compare to those of northwest Europe? Do the Little Divergence between the North Sea and Mediterranean areas find any support in it? A comparison of long-run trends in agricultural output per worker has been carried out between Spain (and to enhance the comparison, also Italy), on the one hand, and Britain and Holland, on the other. Estimates of value added per worker are expressed in pounds sterling of 1910 (adjusted for differences in purchasing power) and derive from O'Brien and Prados de la Escosura (1992). In the case of Spain, the level for 1910 has been projected backwards to 1850 with agricultural labour productivity estimates (Prados de la Escosura, 2003). Then, the

provides an upper bound for our estimates and provides a lower bound for our labour productivity estimates. 
resulting estimates are spliced with the pre-1800 period using productivity estimates for 1790s-1850s (obtained with output per head from the demand approach estimates in Álvarez-Nogal and Prados de la Escosura (2013), and our population and EAP figures). ${ }^{29}$ Labour productivity indices come from Broadberry et al. (2014: 365) and Feinstein (1972), for Britain, van Zanden and van Leeuwen (2012) and Smits et al. (2000), for Holland, and Malanima (2011) and Federico and Malanima (2004) for Italy.

The results are most revealing. In Spain and Italy, initial levels of output per worker are significantly higher than in Britain and Holland, falling during the late sixteenth century and stagnating (Italy) or slightly recovery (Spain) throughout the seventeenth century (Table 5). Meanwhile, output per worker experienced a remarkable improvement in Britain and, especially, in Holland, as output increased and the share of labour force in agriculture declined, unlike the Latin countries' experience. ${ }^{30}$ However, by 1700 only Holland presented significantly higher productivity levels. During the eighteenth century, in spite of the recovery experienced in Spain (that fell short, though, of the 1500s levels), the North-Sea countries forged ahead. Thus, the Little Divergence seems to have emerged after 1700.

From these opposite trends it can be concluded that agriculture played a significant part in the Little Divergence between northwestern and southern Europe. Furthermore, productivity trajectories also suggests that a reversal of fortunes took place as the leading Latin countries at the beginning of the sixteenth century exchanged position with the emerging countries from the North Sea over the early modern era.

\section{Explanatory hypotheses}

Historians of early modern Spain have favoured a-neo-Malthusian interpretation. Demographic expansion in the sixteenth and eighteenth centuries

\footnotetext{
${ }^{29}$ The results match closely direct estimates in Prados de la Escosura, (1988: 123).

${ }^{30}$ Thus, for example, while in Spain agriculture employed about two-thirds of the male labour force by the late eighteenth century (Pérez Moreda, 1999: 54), in Britain it represented just over one-third in 1801, from an initial share of two-thirds in 1522 (Broadberry et al., 2014: 362).
} 
would have led to extending cultivation to marginal lands and, in the absence of capital intensification and technological change, output per worker and per hectare would decline. Conversely, demographic decline in the seventeenth century, by reducing the area of cultivated would have raised output per hectare and per worker.

The available evidence lends support to a different view. Early modern Spain appears as an economy in which the frontier continued expanding beyond the late sixteenth century. In the eighteenth century, for example, agriculture satisfied the increasing demand of food of a growing population at the extensive margin, as large areas of the country were put into cultivation. Landowners who controlled substantial amounts of land put them into cultivation taking advantage of the abundant labour force (Santiago-Caballero, 2013). The elastic supply of land explains how even during the eighteenth century, nearly 2.5 million hectares were put into cultivation (Llopis Agelán, 2002: 128). The expansion of arable lands was not limited to the regions of the south, as the introduction of maize in the north expanded the frontier to lands that were previously unsuitable for the cultivation of other grains (wheat, barley) but had rainfall levels high enough as to make possible maize cultivation. The maize revolution, which started in regions like Asturias, Galicia, and Navarre since mid-seventeenth century, allowed producers to expand cultivated land and increased significantly food production (Floristan Imizcoz, 1985: Diaz Alvarez, 2005). ${ }^{31}$

Trends of output per worker and labour force, rather than moving in opposite directions, as postulated by the neo-Malthusian model, evolved alongside. Even in the phase of the fast expansion of economically active population, 1530-1570, agricultural labour productivity exhibited a positive trend (Figure 8). Output per worker and labour force moved alongside between 1590 and 1800, shrinking between 1590 and 1650 and expanding thereafter, but for a few specific conjunctures in which they moved in opposite directions (i.e., 1570s-80s, 1760s).

Thus, an explanatory hypothesis that combines institutional and climatic dimensions can be proposed as an alternative to the neo-Malthusian interpretation.

\footnotetext{
${ }^{31}$ Estimates for Navarre indicate that, in some areas, the amount of arable land dedicated to the cultivation of grain nearly tripled between 1607 and the eighteenth century (Mikelarena Peña, 1988).
} 
Between the beginnings of sixteenth century and 1570 an economic expansion took place driven by urban growth and international trade. Wool exported to NorthWestern Europe was, aside silver, the most important staple. This expansion increased the demand for agricultural goods, some of them of high-income elasticity (i.e. wine), which led to a rise in the relative price agricultural goods and to an expansion of land under the plough. The rise in relative foodstuffs prices generated incentives to expand production over new land, including the King's baldíos (literally, waste lands, but depicting non-previously cultivated land), which from 1560 were on sale, especially, surroundings of main cities (Madrid, Seville, Valladolid) where the demand for land was more intense (Vassberg, 1975; Álvarez-Nogal, 2001, 2003). During this period the labour force in agriculture expanded rapidly, while agricultural output per worker increased.

After 1570 a more complex scenario appeared. A substantial increase in military expenditure was required as different military conflicts took place in a short time span: the Low Countries rebellion of 1567 and open war after 1573, the Moorish uprising in the Alpujarras in 1569, and the Lepanto battle in 1571. Main taxes were not collected directly by the king but through cities and, in 1574, the king's demand to increase consumption taxes (alcabalas) was rejected by the Castilian cities. This led the king to stop payments to the Genoese bankers between 1575 and 1577, a decision that trickled down, driving local banks into bankruptcy and having deleterious effects on small traders and merchants. Fiscal conflict between cities and the King led to the destruction of local markets from 1570 onwards (Álvarez-Nogal and Chamley, 2014, 2015). Medina del Campo fairs, for example, stopped during three years (1575-1578) and never recovered (Espejo and Paz 1908). Eventually, cities accepted to double alcabalas, opening the way to successive tax increases to be levied on cities (including additional taxes on consumption goods, wine, meat, oil and vinegar, the so called millones) that continued to the 1660s. Meanwhile, Spain's wars extended to England and peaked with the Armada expedition in 1588. War destroyed trade networks and prevented wool exports that never recovered pre-1570 levels (Ruiz Martín, 1968: 133134). Simultaneously, urban decline precluded wool being diverted to the domestic industry. Monetary alterations, especially the devaluation of vellón -a copper currency 
that up to 1602 included a lower proportion of silver (García Guerra, 1999)- also contributed to impeding markets recovery (Álvarez Nogal, 2005). As a result, the economy entered into recession.

Further collapse of urban and external demand, deepened by demographic decline, was fuelled by monetary instability and military conflict in the central decades of the seventeenth century (war with France, 1635-1659; and within Iberia, with the Portuguese, 1640-1668, and Catalan, 1640-1652, rebellions). During these decades it was difficult to recruit soldiers in many Castilian cities and towns, exhausted by previous demand for troops (Camarero Pascual 2015). As a consequence, normal agricultural activities and crops stymied, reducing incentives to cultivate and leading to a less intense use of land.

Climate change also contributed to exacerbating the contraction in agricultural output in late sixteenth and early seventeenth century Spain. Climatic conditions have a significant influence on agrarian output, both in terms of yields and the amount of land cultivated. Lower temperatures affect the metabolisms of the plants by reducing the ability to absorb nutrients and to transport them from the root to the rest of the organism limiting their growth (Rosenzweig, 1998:87). Intensive rainfall has a negative impact on agrarian production, not only by destroying harvests through floods or storms but also by reducing the amount of nutrients in the soil. ${ }^{32}$

Cold (warm) periods in the Northern Hemisphere are associated to wet (dry) phases in Andalusia. ${ }^{33} \mathrm{~A}$ major-rain related events index was computed, in which different scenarios were contemplated and values assigned to each of them: hydrological droughts (absence of rain, drops in river levels) (-2); meteorological droughts (absence of rain) (-1); strong rain (1); and rain-induced flooding (2); and no

\footnotetext{
${ }^{32}$ For instance, up to half of the free nitrogen fixed in the soil can be washed away if winter rains are heavy, reducing considerably the amount of fertilisers available for the growth of the grain (Allen, 2008:187).

${ }^{33}$ It has been shown that phases of the North Atlantic Oscillation (NAO) are strongly and inversely related to seasonal rainfall in Andalusia (around $37^{\circ} \mathrm{N}$ ), with low NAO index levels associated to wet periods and high NAO levels to dry periods (Rodrigo et al. 1999, 2001).
} 
special weather conditions (0) (Rodrigo et al., 1999, 2001). On the basis on monthly evidence from historical records for a large number of localities in Andalusia over 1500-2000 seasonal averages (winter, spring, summer, and autumn) were computed and an annual index of average seasonal rainfall $(R)$ derived. Then, the value of rainfall anomalies $(\mathrm{Z})$ for year $(\mathrm{t})$ was computed with the seasonal rainfall index $(\mathrm{R})$, its mean value $(x)$ and its standard deviation ( $s$ ) for the specific period under consideration (1500-1800, in our case).

$$
Z_{t}=\left(R_{t}-x\right) / s
$$

Rodrigo et al. (2001) find two major wet periods from the late sixteenth to midseventeenth century and from the late eighteenth to the early nineteenth century, that corresponds to the Dalton Minimum (a minimum in solar irradiance) (Rodrigo et al., 2012), with dry periods in the central decades of the sixteenth century and the early eighteenth century. During the Mauder Minimum (1645-1715), a period of minimum sunspots, dry and wet anomalies alternates (Rodrigo et al. 1999: 1248). ${ }^{34}$

In Figure 9 yearly anomalies, or deviations from average relative to the standard deviation -obtained with expression (10)- are provided for cereal output and the index of seasonal rainfall. Cereal production has been preferred to aggregate output, as crops are more sensitive to climate changes than animal produce, another major component of agricultural output. A first glance suggests that wet periods (positive values in the index of precipitation anomalies) tend to correspond to declining output and are concentrated between the late sixteenth and late seventeenth centuries. ${ }^{35}$ Thus, the periods $1590-1608$ and 1618-29, in particular, concentrate the main precipitation anomalies that match the strongest negative fluctuations in agricultural output. The Mauder Minimum, with its alternate wet and dry periods, also seems to reflect on output volatility in the late seventeenth and early

\footnotetext{
${ }^{34}$ These results largely match those obtained from rogations in Catalonia which suggests a wet era from 1570 to the early seventeenth century and dry periods over 1530-1550, 1630-1640, and between 1680 and the early eighteenth century (Barriendos, 1994).

${ }^{35}$ This finding seems to contradict Rodrigo et al. (2012: 129) suggestion that droughts have a more deleterious impact on output.
} 
eighteenth century. Another climatic shift, the 'Maldá Anomaly', that brought with it an increase in the number of successive climatic disasters (floods, droughts, and sea storms), seems to correspond to more intense output fluctuations in the late eighteenth century (Barriendos and Llasat, 2003). On the whole, an inverse association between output and rainfall anomalies can be predicated for early modern Spain, with wet periods associated to negative output fluctuations.

\section{Concluding Remarks}

Trends in agricultural output during three centuries have been estimated on the basis of a large tithe database. Over the long run, agricultural output per head evolved in parallel with population, supporting the view of Spain as a land abundant frontier economy.

Two different paths are found in agricultural performance. A high path in output per head up the late sixteenth century was broken by a severe contraction over 1570-1590, initiating a low path that lasted to 1800 . An affluent agriculture with relatively high levels of output per head and per worker was, thus, replaced by another one of low levels that persisted to the nineteenth century.

In comparative perspective, starting from higher levels, agricultural labour productivity in Spain remained stagnant and, along Italy's, fell behind Britain and Holland's levels with a substantial gap emerging over the eighteenth century. Thus, in a reversal of fortune, Spanish agriculture contributed to Europe's Little Divergence.

On the basis of our new findings some explanatory hypotheses of the role of agriculture in Spain's decline can be put forward as an alternative to the neoMalthusian interpretation. A relatively affluent, urbanized society declined as a result of institutional factors intensified by climate anomalies. Agricultural decline appears to be largely the result of a tax-induced deep contraction in urban and international demand at time of war. The destruction of a fragile urban and international commercial network reduced incentives to produce for the market and led to a less intensive use of labour and land. 


\section{References}

ACEMOGLU, D. and ROBINSON, J.A. (2012). Why Nations Fail. The Origins of Power, Prosperity and Poverty, London: Profile Books.

ALLEN, R. C. (2000). "Economic structure and agricultural productivity in Europe. 13001800". European Review of Economic History 4, 1-25.

ALLEN, R.C. (2008) The Nitrogen Hypothesis and the English Agricultural Revolution: A Biological Analysis. Journal of Economic History, 68, 182-210.

ALVAREZ VAZQUEZ, J.A. (1984). Los Diezmos en Zamora (1500-1840). SALAMANCA: Ediciones Universidad de Salamanca.

ALVAREZ-NOGAL, C. and CHAMLEY, C. (2014). Debt Policy under Constraints between Philip II, the Cortes and Genoese bankers. Economic History Review 67, 192-213.

ALVAREZ-NOGAL, C. and CHAMLEY, C. (2015). Philip II against the Cortes and the Credit Freeze of 1575-1577. Universidad Carlos III Working Papers in Economic History 15-06.

ALVAREZ-NOGAL, C. (2001). Los problemas del vellón en el siglo XVII. ¿Se consiguió abaratar la negociación del crédito imponiendo precios máximos a la plata? Revista de Historia Económica, 17-37.

ALVAREZ-NOGAL, C. (2003). Agrarian Institutions and Economic Growth: Was the sale of baldíos responsible of the Castilian Agrarian Crisis at the end of the sixteenth century? Universidad Carlos III Working Paper in Economic History 03-01.

ALVAREZ-NOGAL, C. (2005). Incentivos económicos y derechos de propiedad en la Castilla del siglo XVI. Cuadernos de ICE 70, 77-96.

ALVAREZ-NOGAL, C. and PRADOS DE LA ESCOSURA, L. (2007). The Decline of Spain (1500-1850): Conjectural Estimates. European Review of Economic History 11, 319-66.

ALVAREZ-NOGAL, C. and PRADOS DE LA ESCOSURA, L. (2013). The Rise and Fall of Spain, 1270-1850. Economic History Review 66, 1-37.

ANDRES-GALLEGO, J. (1973). Datos de la economía rural castellana (1676-1800). Hispania: Revista Española de Historia 125, 597-627.

ANES, G. (1970). Las crisis agrarias en la España Moderna. Madrid: Taurus.

ANES, G. and GARCIA SANZ, A. (1982). Dime et production agraire dans I'Espagne moderne, de la fin du XVIe au milieu du XIXe siècle. In J. GOY and E. LE ROY LADURIE, (eds.), Prestations Paysannes, Dîmes, Rente Foncière et Mouvements de la Production Agricole à l'époque Préindustrielle. Paris: Éditions de l'École des Hautes Études en Sciences Sociales.

ANES, G. and LE FLEM, J.P. (1965). La crisis del siglo XVII. Producción agrícola, precios e ingresos en tierras de Segovia. Moneda y Crédito 93, 3-55.

ARDIT LUCAS, M. (1987). Expulsió dels moriscos i creixement agrari al País Valencià. Afers: Fulls de Recerca i Pensament 3, 273-316.

ARDIT LUCAS, M. (1989). Recaudación y fraude diezmal en el siglo XVIII valenciano. In Ministerio de Agricultura, Pesca y Alimentación, Estructura agrarias y reformismo 
ilustrado en la España del siglo XVIII. Madrid: Ministerio de Agricultura, Pesca y Alimentación.

BADOSA i COLL, E. (1978). El desenvolupament de tres explotacions agrícoles en el segle XVIII (1715-1769). Estudis d'Història Agrària 1, 179-207.

BAEHREL, R. (1961). Une Croissance. La Basse-Provence Rurale (Fin du XVle Siècle1789). Paris: S.E.V.P.E.N.

BARRIENDOS, M. (1994). Climatología histórica de Catalunya. Aproximación a sus características generales (ss. XV-XIX). Barcelona: Departamento de Geografía Física y Análisis Geográfico Regional, Universidad de Barcelona, Ph.D. Thesis.

BARRIENDOS, M. and LLASAT, M.C (2003). The Case of the 'Maldá' Anomaly in the Western Mediterranean Basin (AD 1760-1800): An Example of a Strong Climatic Variability. Climatic Change 61, 191-216.

BELASCOAIN CEMBORAIN, P. (2011). Sangüesa: historia de un pueblo.

http://www.historiadesanguesa.es.

BENITEZ SANCHEZ-BLANCO, R. (1982). Diezmos andaluces: series malagueñas del diezmo del trigo. In J. GOY, and E. LE ROY LADURIE, (eds.), Prestations Paysannes, Dîmes, Rente Foncière et Mouvements de la Production Agricole à l'époque Préindustrielle. Paris: Éditions de l'École des Hautes Études en Sciences Sociales.

BILBAO BILBAO, L.M. and FERNANDEZ DE PINEDO, E. (1984). La Producción Agrícola en el País Vasco (1537-1850). Cuadernos de Sección de Eusko Ikaskuntza. HistoriaGeografía, 83-196.

BOIS, G. (1984). The Crisis of Feudalism: Economy and Society in Eastern Normandy, c. 1300-1550. Cambridge: Cambridge University Press.

BORAH, W. (1941). The collection of tithes in the Bishopric of Oaxaca during the sixteenth century. The Hispanic American Historical Review 21, 386-409.

BORAH, W. (1949). Tithe collection in the Bishopric of Oaxaca, 1601-1867. The Hispanic American Historical Review 29, 498-517.

BOYD, C. E. (1952). Tithes and Parishes in Mediaeval Italy. The Historical Roots of a Modern Problem. Ithaca: Cornell University Press.

BROADBERRY, S., CAMPBELL, B.M.S., KLEIN, A., OVERTON, M. and VAN LEEUWEN, B. (2014). British Economic Growth, 1270-1870. Cambridge: Cambridge University Press.

BROADBERRY, S.N. (2013). Accounting for the Great Divergence. LSE Economic History Working Papers 184/2013.

BUSTELO, F. (1972a). Algunas reflexiones sobre la población española de principios del siglo XVIII. Anales de Economía 15, pp. 89-106.

BUSTELO, F. (1972b). La población española en la segunda mitad del siglo XVIII. Moneda y Crédito 123, pp. 53-104.

CABO ALONSO, A. (1955). La Armuña y su evolución económica. Estudios Geográficos $58,73,136$. 
CAMARERO PASCUAL, R. (2015). La guerra de recuperación de Cataluña (1640-1652). Madrid, Actas.

CARRERAS, A. (2003). Modern Spain. In J. MOKYR (ed.), The Oxford Encyclopedia of Economic History. New York: Oxford University Press.

CASADO ALONSO, H. (1991). Producción agraria, precios y coyuntura económica en las diócesis de Burgos y Palencia a fines de la Edad Media. Studia Historica. Historia Medieval 9, 67-109.

CASEY, J. (1979). The Kingdom of Valencia in the Seventeenth Century. Cambridge: Cambridge University Press.

CLARK, G. (2002). Land rental values and the agrarian economy: England and Wales, 1500-1914. European Review of Economic History 6, 281-308.

DAVIU y PONS, G. (1978). La producció d'oli a Mallorca. Segle XVIII. Aproximació en base a la documentació fiscal. In 1er Col-loqui de Historia Agrària. Valencia: Institució Alfons el Magnànim.

DERVILLE, A. (1987). Dimes, rendements du blé et "révolution agricole" dans le nord de la France au Moyen Age. Annales E. S. C 42, 1411-32.

DEYON, P. (1967). Contribution a l'étude des revenus fonciers en Picardie. Les fermages de l'Hôtel-Dieu d'Amiens et leurs variations de 1515 à 1789. Lille.

DIAZ ALVAREZ, J. (2005) Crisis agrarias en la Asturias del siglo XVII: una aproximación a su estudio. Revista de Historia Moderna: Anales de la Universidad de Alicante 23, 307322.

DODDS, B. (2004). Estimating Arable Output Using Durham Priory Tithe Receipts, 13411450. Economic History Review 57, 245-285.

DODDS, B. (2007). Peasants and Production in the Medieval North-East: the Evidence from Tithes, 1270-1536. Woodbridge: Boydell \& Brewer.

DOMINGUEZ ORTIZ, A. and VINCENT, B. (1993). Historia de los moriscos. Vida y tragedia de una minoría. Madrid: Alianza Editorial.

EIRAS ROEL, A. (1982). Dîme et mouvement du produit agricole en Galice, 1600-1837. In J. GOY, and E. LE ROY LADURIE, (eds.), Prestations Paysannes, Dîmes, Rente Foncière et Mouvements de la Production Agricole à l'époque Préindustrielle. Paris: Éditions de l'École des Hautes Études en Sciences Sociales.

ELLIOTT, J. H. (1961). The Decline of Spain. Past and Present 20, 52-75.

ESPEJO, C. and PAZ, J. (1908). Las Antiguas Ferias de Medina del Campo. Valladolid: Imprenta La Nueva Pincia.

EVANS, E. J. (1976). The Contentious Tithe: The Tithe Problem and English Agriculture, 1750-1850. London: Routledge \& Kegan Paul.

FEDERICO, G. and MALANIMA, P. (2004). Decline, Growth: Product and Productivity in Italian Agriculture, 1000-2000. Economic History Review 57, 437-464.

FEINSTEIN, C.H. (1972). National Income, Expenditure and Output of the United Kingdom, 1855-1965. Cambridge: Cambridge University Press. 
FELIU, G. (1991). Precios y salarios en la Cataluña moderna. 2 vols. Madrid: Banco de España.

FLORISTAN IMIZCOZ, A. (1985) Evolución de la población de Navarra en el siglo XVII. Príncipe de Viana, 46 (174), 1985, 205-234.

FONTANA, J. (1967). El “Censo de frutos y manufacturas" de 1799: un análisis critico. Moneda y Crédito 101, 54-68.

FRADERA, J.M. (1978). Evolució del delme i les finances de Santa Maria de Mataró, 1727-1835. In 1er Col-loqui de Historia Agrària. Valencia: Institució Alfons el Magnànim.

GARCIA GUERRA E. (1999). Las Acuñaciones de Vellón Durante el Reinado de Felipe III. Madrid: Banco de España.

GARCIA SANZ, A. (1977). Desarrollo y Crisis del Antiguo Régimen en Castilla la Vieja. Economía y Sociedad en Tierras de Segovia, 1500-1814. Madrid: Akal.

GARCIA SANZ, A. (1979). La evolución de la producción de cereales y leguminosas en Castilla la Vieja de 1570 a 1800: los diezmos del obispado de Segovia. Anales del CUNEF, 223-46.

GARCIA SANZ, A. (1982). La producción de cereales y leguminosas en Castilla la Vieja. Los diezmos del Obispado de Segovia de 1570 a 1800. In J. GOY, and E. LE ROY LADURIE, (eds.), Prestations Paysannes, Dîmes, Rente Foncière et Mouvements de la Production Agricole à l'époque Préindustrielle. Paris: Éditions de l'École des Hautes Études en Sciences Sociales.

GARCIA SANZ, A. (1985). Crisis de la agricultura tradicional y revolución liberal (1800 1850). In A. GARCÍA SANZ and R. GARRABOU, (eds.), Historia agraria de la España contemporánea. 1. Cambio social y nuevas formas de propiedad. Barcelona: Crítica, pp. 7-99.

GARCÍA SANZ, A. (1994). La ganadería española entre 1750 y 1865: los efectos de la reforma agraria liberal. Agricultura y Sociedad 72, 81-119.

GARZON PAREJA, M. (1974). Diezmos y Tributos del Clero de Granada. Granada: Archivo de la Real Chancillería.

GARZON PAREJA, M. (1982). Tributos campesinos a la Iglesia en el Reino de Granada, 1545-1800. In J. GOY, and E. LE ROY LADURIE, (eds.), Prestations Paysannes, Dîmes, Rente Foncière et Mouvements de la Production Agricole à l'époque Préindustrielle. Paris: Éditions de l'École des Hautes Études en Sciences Sociales.

GEHR [GRUPO DE ESTUDIOS DE HISTORIA RURAL] (1978-1979). Contribución al análisis histórico de la ganadería española, 1865-1929. Agricultura y Sociedad, 8, 129-182; 10, 105-169.

GONZALEZ ARCE, J.D. (2015). La producción oleícola del Aljarafe según el diezmo del almojarifazgo de Sevilla (siglo XV). Historia Agraria 65, 1139-1472.

GONZALEZ GOMEZ, A. (1980). Producción y precio de cereales en Trigueros (Huelva) 1450-1512. En la España Medieval, 129-142.

GOUBERT, P. (1960). Beauvais et le Beauvaisis de 1600 à 1730, Paris: S.P.E.V.E.N. 
GOY, J. and LE ROY LADURIE, E. (eds.) (1972). Les Fluctuations du Produit de la Dime. Conjoncture Décimale et Domaniale de la fin du Moyen-Age au XVIIle Siècle. Paris: Éditions de l'École des Hautes Études en Sciences Sociales.

GOY, J. and LE ROY LADURIE, E. (eds.) (1982). Prestations Paysannes, Dimes, Rente Foncière et Mouvement de la Production Agricole a l'époque Préindustrielle. Paris: Editions de L'Ecole des Hautes Etudes en Sciences Sociales.

GRAFE, R. (2012). Distant Tyranny. Markets, Power, and Backwardness in Spain, 16501800. Princeton: Princeton University Press.

GRUPO '75 (1977). La economía del Antiguo Régimen. La "Renta Nacional" de la Corona de Castilla. Madrid: Universidad Autónoma de Madrid.

HAMILTON, E.J. (1934). American Treasure and the Price Revolution in Spain, 15011650. Cambridge, Mass.: Harvard University Press.

HAMILTON, E.J. (1947). War and Prices in Spain, 1651-1800. Cambridge, Mass.: Harvard University Press.

HERNANDEZ GARCIA, R. and PEREZ ROMERO, E. (2008). La evolución del producto agrario en Castilla y León durante la Edad Moderna. Problemas y posibilidades para su estimación a partir de las fuentes diezmales. Paper presented in the IX Congress of the Spanish Association of Economic History, Murcia.

IBAÑEZ RODRIGUEZ, S. and ALONSO CASTROVIEJO, J.J. (1996). Especialización agraria en el alto Ebro (La Rioja) La Cultura del vino, 1500-1800. Brocar 20. 211-35.

KAIN, R. (1979). Tithe as an Index of Pre Industrial Agricultural Production. Agricultural History Review 27, 73-81

KIRILLY, Z. and KISS, I. N. (1968). Production de céréales et exploitations paysannes en Hongrie aux XVIe-XVIle siècles. Annales E.S.C. 6, 1211-1236.

LABROUSSE, E. (1962), Fluctuaciones económicas e historia social. Madrid: Tecnos. LADERO QUESADA, M.A. (1979). Diezmo Eclesiástico y Producción de Cereales en el Reino de Sevilla (1408-1503). Sevilla: Universidad de Sevilla.

LANZA GARCIA, R. (1991). La Población y el Crecimiento Económico de Cantabria en el Antiguo Régimen. Madrid: Universidad de Cantabria.

LATORRE CIRIA J.M. (2007). La producción agraria en el sur de Aragón (1660-1827). Historia Agraria 41, 3-30.

LATORRE CIRIA, J.M. (1989). Diezmo y producción de vino en Huesca (siglo XVI). Argensola: Revista de Ciencias Sociales del Instituto de Estudios Altoaragoneses, 151162.

LE ROY LADURIE E. and GOY, J. (1982). Tithe and Agrarian History from the Fourteenth to the Nineteenth Centuries: An Essay in Comparative History. Cambridge: Cambridge University Press.

LE ROY LADURIE, E. (1966). Les Paysans de Languedoc, Paris: Flammarion. 
LEIJONHUFVUD, L. (2001). Grain tithes and manorial yields in early modern Sweden: trends and patterns of production and productivity, c. 1540-1680. Acta Universitatis Agriculturae Sueciae Agraria, 309 (Uppsala, 2001).

LEMENEUNIER, G. (1982). Approche méthodologique des dîmes de Murcie à l'époque moderne. In J. GOY, and E. LE ROY LADURIE, (eds.), Prestations Paysannes, Dîmes, Rente Foncière et Mouvements de la Production Agricole à l'époque Préindustrielle. Paris: Éditions de l'École des Hautes Études en Sciences Sociales.

LLOPIS AGELÁN, E. (1979). Las economías monásticas al final del Antiguo Régimen en Extremadura. Ph.D. Thesis Universidad Complutense Madrid.

LLOPIS AGELÁN, E. (2002). Expansión, reformismo y obstáculos al crecimiento (17151840). In F. COMIN, M. HERNANDEZ, AND E. LLOPIS AGELÁN, (eds.), Historia económica de España. Barcelona: Critica.

LLOPIS AGELÁN, E. (2004). El crecimiento de la población española, 1700-1849: índices regionales y nacional de bautismos. Áreas 24, 9-24.

LLOPIS AGELÁN, E. And J.A. SEBASTIÁN AMARILLA (2007). La economía española en el Antiguo Régimen: balance y legado. In R. DOBADO, A. GÓMEZ GALVARRIATO, and G. MÁRQUEZ (eds.), España y México. ¿Historias económicas paralelas?. Mexico City: Fondo de Cultura Económica, pp. 47-96.

LLOPIS AGELAN, E. and GONZÁLEZ MARISCAL, M. (2010). Un crecimiento tempranamente quebrado: el producto agrario en Andalucía occidental en la Edad Moderna. Historia Agraria 50, 13-42.

LÓPEZ-SALAZAR PEREZ, J and MARTIN GALÁN, M.M. (1981). La producción cerealista en el arzobispado de Toledo: 1463-1699. Cuadernos de Historia Moderna y Contemporánea 2, 21-104.

MACÍAS HERNÁNDEZ, A. M. (1984). La producción de cereales de Canarias: el ejemplo del trigo (1610-1820). Actas del Congreso de Historia Rural, Siglos XV al XIX. Madrid: Universidad Complutense.

MALANIMA, P. (2007). Wages, productivity and working time in Italy, 1270-1913. Journal of European Economic History 36, 127-171.

MALANIMA, P. (2011). The Long Decline of a Leading Economy: GDP in Central and Northern Italy, 1300-1913. European Review of Economic History 15, 169-219.

MARTÍNEZ SHAW, C. (1994). La emigración española a América (1492-1824). Colombres, Asturias: Fundación Archivo de Indianos.

MATILLA TASCÓN, A. (1947). La única contribución y el Catastro de Ensenada. Madrid: Servicio de Estudios de la Inspección General del Ministerio de Hacienda.

MELON JIMENEZ, M.A. (1987) Los diezmos de la diócesis de Coria (1566-1773). Studia Historica 5, 177-190.

MELON JIMENEZ, M.A. (1998). El diezmo de los ganados trashumantes. Un estudio sobre sus peculiaridades en Extremadura. Studia Historica. Historia Moderna 18, $321-$ 52 
MIKELARENA PEÑA, F. (1988) Demografía y economía de Cinco Villas en el XVII: El sentido de la crisis. Príncipe de Viana, 49 (183), 127-154.

MORINEAU, M. (1970). Les Faux-semblants d'un Démarrage Économique: Agriculture et Démographie en France au XVIII e Siècle. Paris: A. Colin.

MORNER, M. (1995). Spanish Historians on Spanish Migration to America during the Colonial Period. Latin American Research Review 30, 251-267.

NADAL, J. (1984). La población española durante los siglos XVI, XVII y XVIII. Un balance a escala regional. In V. Pérez Moreda and D. S. Reher (eds.), Demografía histórica en España. Madrid: El arquero, pp. 39-54.

NADAL, J. (1988). La población española durante los siglos XVI, XVII y XVIII. Un balance a escala regional. In V. PEREZ MOREDA and D.S. REHER (eds.), Demografía histórica en España. Madrid: El Arquero.

NEVEUX, H. (1980). Les Grains du Cambrésis (Fin du XIVe-début du XVIle Siècles). Vie et Déclin d'un Structure Economique. Ph.D. Thesis, Université Paris-Sorbonne. Paris.

NICOLAU, R. (2005). Población, salud y actividad. In A. Carreras and X. Tafunell (eds.), Estadísticas históricas de España. 3 vols. Madrid: Fundación BBVA, I, pp. 77-154.

O'BRIEN, P.K. AND PRADOS DE LA ESCOSURA, L. (1992). Agriculture and European Industrialization, 1890-1980. Economic History Review 45, 514-536 (Data Appendix in Universidad Carlos III Working Papers 92-19, May 1992).

OLSSON, M. and SVENSSON, P. (2010). Agricultural growth and institutions: Sweden, 1700-1860. European Review of Economic History 14, 275-304.

PALOP RAMOS, J.M. (1982). El producto diezmal valenciano durante los siglos XVII y XVIII. Aproximación a su estudio. In J. GOY, and E. LE ROY LADURIE, (eds.), Prestations Paysannes, Dîmes, Rente Foncière et Mouvements de la Production Agricole à l'époque Préindustrielle. Paris: Éditions de l'École des Hautes Études en Sciences Sociales.

PEREIRA IGLESIAS, J.L. (1990). Cáceres y su Tierra en el Siglo XVI. Economía y sociedad. Cáceres: Institución Cultural El Brocense.

PEREZ MOREDA, V. (1982a). Actividad y ocupación de la población masculina española de fines del siglo XVIII a fines del siglo XIX. Unpublished manuscript. Madrid: Banco de España.

PEREZ MOREDA, V. (1982b). La población activa española y su distribución sectorial de fines del siglo XVIII a 1877. Unpublished manuscript. Madrid: Banco de España.

PEREZ MOREDA, V. (1988). La población española. In M. ARTOLA (ed.), Enciclopedia de historia de España, 1: Economía y sociedad. Madrid: Alianza, pp. 345-431.

PEREZ MOREDA, V. (1999). Población y economía en la España de los siglos XIX y XX. In G. ANES. Historia Económica de España Siglos XIX y XX. Barcelona: Galaxia Gutenberg.

PHILLIPS, C. R. and PHILLIPS, W. D. (1997). Spain's Golden Fleece: Wool Production and the Wool Trade from the Middle Ages to the Nineteenth Century. Baltimore: Johns Hopkins University Press.

POLO Y CATALINA, J. (1803), Censo de frutos y manufacturas de España e islas adyacentes, Madrid: Imprenta Real. 
PONSOT, P. (1986). Atlas de Historia Económica de la Baja Andalucía (Siglos XVI-XIX). Seville: Editoriales Andaluzas Unidas.

PÖSHCHL, A. (1927). Das karolingische Zehent gebot in wirtschaftsgeschichtlicher Beleuchtung. Graz: Leuschner \& Lubensky's Universitäts-Buchhandlung.

PRADOS DE LA ESCOSURA, L. (1988). De imperio a nación. Madrid: Alianza.

RICARDO, D. $(1817,1951)$. On the Principles of Political Economy, and Taxation, Cambridge: Cambridge University Press.

RODRIGO, F. S., ESTEBAN-PARRA, M.J., POZO-VÁZQUEZ, D., and CASTRO-DIEZ, Y. (1999). A 500-Year Precipitation Record in Southern Spain. International Journal of Climatology 19: 1233-1253.

RODRIGO, F. S., POZO-VÁZQUEZ, D., ESTEBAN-PARRA, M.J. and CASTRO-DIEZ, Y. (2001). A reconstruction of the winter North Atlantic Oscillation index back to A.D. 1501 using documentary data in southern Spain. Journal of Geophysical Research 106, D14, 14805-14818.

RODRIGO, F. S., GÓMEZ-NAVARRO, J.J., AND MONTÁVEZ GÓMEZ (2012). Climate variability in Andalusia (southern Spain) during the period 1701-1850 based on documentary sources: evaluation and comparison with climate model simulations. Climate of the Past 8, 117-133

RODRIGUEZ CANCHO, M., MELON JIMENEZ, M.A., RODRIGUEZ GRAJERA, A., and BLANCO CARRASCO, J.P. (2005). Economía eclesiástica en Extremadura a finales del Antiguo Régimen. Una aproximación a las rentas de la diócesis de Plasencia. Obradoiro de Historia Moderna 13, 127-61.

ROSENZWEIG, C. (1998). Climate Change and the Global Harvest: Potential Impacts of the Greenhouse Effect on Agriculture. New York: Oxford University Press.

RUIZ MARTIN, F. (1968). Las finanzas españolas en el reinado de Felipe II, Cuadernos de Historia. Anexo de Hispania, 2, 118-121.

RUWET, J. (1964). La mesure de la production agricole sous I'Ancien Régime. Annales 19, 625-42.

SALVADOR ESTEBAN, E. (2004). Tercios diezmos sobre la producción agraria de la huerta de Valencia en el siglo XVI. Aproximación a su naturaleza y rendimiento. Estudis d'Història Agraria 17, 861-76.

SANTIAGO-CABALLERO, C. (2011). Income inequality in central Spain, 1690-1800. Explorations in Economic History 48, 83-96.

SANTIAGO-CABALLERO, C. (2013). The Rain in Spain? Climate versus Urban Demand as Causes of Agricultural Stagnation in Eighteenth Century Spain. European Review of Economic History 17, 452-70.

SANTIAGO-CABALLERO, C. (2014). Tithe series and grain production in central Spain (1700-1800). Rural History 25, 15-37

SEBASTIAN AMARILLA, J.A. (1992). Agricultura y rentas monásticas en tierras de León: Santa María de Sandoval (1167-1835), Ph.D. Thesis. Universidad Complutense, Madrid. 
SERRA i PUIG, E. (1978). Consideracions entorn de la producció i la productivitat agràries de la Catalunya del segle XVII. Estudis d'història Agrària 1, 120-53.

SERRA, E. (1988). Pagesos i Senyors a la Catalunya del Segle XVII. Baronia de Sentmenat 1590-1729. Barcelona: Critica.

SIMPSON, J. (1992). Technical change, labour absorption and living standards in rural Andalucía 1886-1936. Agricultural History 66, 3, pp. 1-24.

SMITS, J.-P., HORLINGS, E., VAN ZANDEN, J.L. (2000). Dutch GNP and Its Components, 1800-1913. Groningen: Groningen Growth and Development Centre.

VASSBERG, D. (1975). The sale of Tierras Baldías in Sixteenth-Century Castile. Chicago: University of Chicago.

VIARD, P. (1909) Histoire de la Dime Ecclésiastique Principalement en France, Jusqu'au Décrète de Gratien. Dijon: Jobard.

VIARD, P. (1911). La dime ecclésiastique dans le royaume d'Arles et de Vienne aux XIle et XIIle siècles. Zeitschrift der Savigny-Stiftung für Rechtsgeschichte, Kanonistische Abteilung 1, 126-59.

VIARD, P. (1912). Histoire de la Dime Ecclésiastique dans le Royaume de France aux XXIle et XXIIle Siècles (1150-1313). Paris: A. Picard.

VIARD, P. (1913). L'évolution de la dime ecclésiastique en France aux xiv' et XVe siècles. ibid., xxxiv (1913), Zeitschrift der Savigny-Stiftung für Rechtsgeschichte, Kanonistische Abteilung 3, 107-40.

VIARD, P. (1914). Historie de la Dime Ecclésiastique en France au xvi- Siècle. Paris: A. Picard.

VICEDO I RIUS, E. (1982). Propietat, accés a la terra i distribució dels ingressos a la Lleida del segle XVIII. Recerques: Història, Economia, Cultura 12, 57-90.

VIDAL, J.J. (1978). La evolución de la producción agrícola en Mallorca durante la Edad Moderna. Fuentes y problemas de su estudio. Moneda y Crédito 145, 67.

WRIGLEY, E. A. (1985). Urban growth and agricultural change: England and the continent in the early modern period. Journal of Interdisciplinary History 10, 683-728.

YUN CASALILLA, B. (1994). Proposals to quantify long-term performance in the Kingdom of Castile, 1550-1800. In A. MADDISON and H. VAN DER WEE (eds.), Economic Growth and Structural Change: Comparative Approaches over the Long Run. Milan: Università Bocconi.

ZANDEN, J.L. VAN and VAN LEEUWEN, B. (2012). Persistent but not consistent: The growth of national income in Holland 1347-1807. Explorations in Economic History 49, 119-130. 
Table 1

Main Components of Agricultural Output, 1500-1800: Growth Rates (\%)

$\begin{array}{lrrrrr} & \text { Cereals } & \text { Olive Oil } & \text { Wine } & \text { Legumes \& Fruit } & \text { Livestock } \\ & & & & & \\ 1500 / 9-1790 / 9 & 0.04 & 0.04 & 0.27 & 0.37 & 0.26 \\ & & & & & \\ 1500 / 9-1560 / 9 & 0.37 & 0.47 & 1.19 & 0.30 & 0.55 \\ 1560 / 9-1640 / 9 & -0.50 & -0.55 & -0.89 & 0.10 & -0.18 \\ 1560 / 9-1610 / 9 & -0.66 & -0.85 & -0.93 & -0.13 & -0.67 \\ 1610 / 9-1640 / 9 & -0.24 & -0.06 & -0.82 & 0.47 & 0.63 \\ 1640 / 9-1750 / 9 & 0.28 & 0.55 & 0.71 & 0.58 & 0.55 \\ 1750 / 9-1790 / 9 & -0.02 & -0.83 & -0.02 & 0.45 & -0.09 \\ & & & & & \\ 1500 / 9-1520 / 9 & -0.53 & -4.31 & 1.95 & -0.97 & 0.57 \\ 1520 / 9-1560 / 9 & 0.83 & 2.86 & 0.82 & 0.94 & 0.54 \\ 1560 / 9-1580 / 9 & -0.70 & -2.77 & -0.58 & 0.84 & -1.08 \\ 1580 / 9-1610 / 9 & -0.64 & 0.43 & -1.17 & -0.78 & -0.39 \\ & & & & & \\ 1640 / 9-1690 / 9 & 0.15 & 0.22 & 0.93 & 0.24 & 0.44 \\ 1690 / 9-1750 / 9 & 0.39 & 0.83 & 0.52 & 0.87 & 0.64 \\ 1750 / 9-1760 / 9 & -1.63 & 0.43 & -0.87 & -0.48 & -0.76 \\ 1760 / 9-1790 / 9 & 0.52 & -1.25 & 0.26 & 0.76 & 0.13\end{array}$

Sources: Appendix A, Table A-1. See text. 
Table 2

Agricultural Output Growth, 1500-1800: Upper and Lower Bound Estimates (\%)

$\begin{array}{lrr} & \begin{array}{r}\text { Total Output } \\ \text { (Upper bound) }\end{array} & \begin{array}{r}\text { Total Output } \\ \text { (Lower bound) }\end{array} \\ 1500 / 9-1790 / 9 & 0.19 & 0.17 \\ & & \\ 1500 / 9-1560 / 9 & 0.53 & 0.53 \\ 1560 / 9-1640 / 9 & -0.36 & -0.41 \\ 1560 / 9-1610 / 9 & -0.60 & -0.61 \\ 1610 / 9-1640 / 9 & 0.03 & -0.07 \\ 1640 / 9-1750 / 9 & 0.47 & 0.43 \\ 1750 / 9-1790 / 9 & 0.03 & 0.05 \\ & & \\ 1500 / 9-1520 / 9 & -0.19 & -0.32 \\ 1520 / 9-1560 / 9 & 0.89 & 0.96 \\ 1560 / 9-1580 / 9 & -0.83 & -0.80 \\ 1580 / 9-1610 / 9 & -0.45 & -0.49 \\ 1640 / 9-1690 / 9 & & \\ 1690 / 9-1750 / 9 & 0.32 & 0.28 \\ 1750 / 9-1760 / 9 & 0.60 & 0.55 \\ 1760 / 9-1790 / 9 & -0.92 & -0.93 \\ & 0.34 & 0.38\end{array}$

Note: The upper and lower bounds correspond to animal produce value added shares of 31 and $19.8 \%$.

Sources: Appendix A, Table A-1. See text. 
Table 3

Agricultural Output per Head Growth, 1500-1800 (\%)

$\begin{array}{rr}\begin{array}{r}\text { Output per head } \\ \text { (Tithes approach) } \\ \text { (Upper bound) }\end{array} & \begin{array}{r}\text { Output per head } \\ \text { (Demand approach) }\end{array} \\ -0.09 & -0.14 \\ -0.01 & -0.18 \\ -0.72 & -0.30 \\ 0.14 & -0.02 \\ -0.25 & -0.27 \\ & \\ -0.35 & -0.17 \\ 0.16 & -0.19 \\ -1.32 & -0.20 \\ -0.31 & -0.37 \\ 0.21 & -0.51 \\ 0.15 & 0.37 \\ -0.55 & 0.73 \\ 0.21 & -0.17 \\ -1.55 & -0.88 \\ 0.19 & -0.06\end{array}$

Sources: Appendix A, Table A-3. See text. 
Table 4

Agricultural Output per Economically Active Population Growth, 1500-1800 (\%)

Output per EAP

1500/9-1790/9

1500/9-1560/9

1560/9-1610/9

1610/9-1750/9

1750/9-1790/9

1500/9-1520/9

1520/9-1560/9

1560/9-1580/9

1580/9-1610/9

1610/9-1640/9

1640/9-1680/9

1680/9-1690/9

1690/9-1750/9

1750/9-1760/9

1760/9-1790/9
$-0.02$

0.06

$-0.67$

0.20

$-0.11$

$-0.28$

0.23

$-1.25$

$-0.29$

0.04

0.41

$-0.46$

0.25

$-1.39$

0.32
Output per EAP

(Simulation)*

$-0.09$

$-0.01$

$-0.75$

0.13

$-0.18$

$-0.35$

0.16

$-1.32$

$-0.36$

$-0.03$

0.34

$-0.53$

0.18

$-1.47$

0.25

Note: * Simulation assuming a constant share (0.66) of labour force in agriculture. Sources: Appendix A, Table A-4. See the text. 
Table 5

\section{Comparative Agricultural Labour Productivity}

\section{(1910 $€$ per worker, British relative prices)}

$\begin{array}{rrrrrrr} & \text { Spain } & \text { Italy } & & \text { Holland } & \text { Britain } \\ 1510 / 9 & 24.8 & 25.0 & 1510 & 20.7 & 1522 & 17.9 \\ 1580 / 9 & 19.8 & 21.4 & & & & \\ 1700 / 9 & 21.9 & 21.9 & 1700 & 29.1 & 1700 & 22.6 \\ 1750 / 9 & 24.1 & 22.8 & & & 1759 & 31.6 \\ 1790 / 9 & 23.1 & 19.9 & 1807 & 34.7 & 1801 & 37.5\end{array}$

Sources: Britain, Broadberry et al. (2014: 365) and Feinstein (1972). Holland, van Zanden and van Leeuwen (2012) and van Zanden et al. (2000). Italy, Malanima (2011) and Federico and Malanima (2004). Data for Holland kindly provided by the authors. Spain, Appendix, Table A.4), see text. Levels of output per worker c. 1910 expressed in purchasing power parity (Paasche PPPs), O'Brien and Prados de la Escosura (1992) Appendix A, except for Holland, for which it was used the trading exchange rate (ER) in the absence of PPP exchange (PPP) rate between the guilder and the sterling. The underlying assumption is that two developed and open economies in northwestern Europe such as the Netherlands and Britain had close price levels (PL) (being, PL = PPP /ER). 


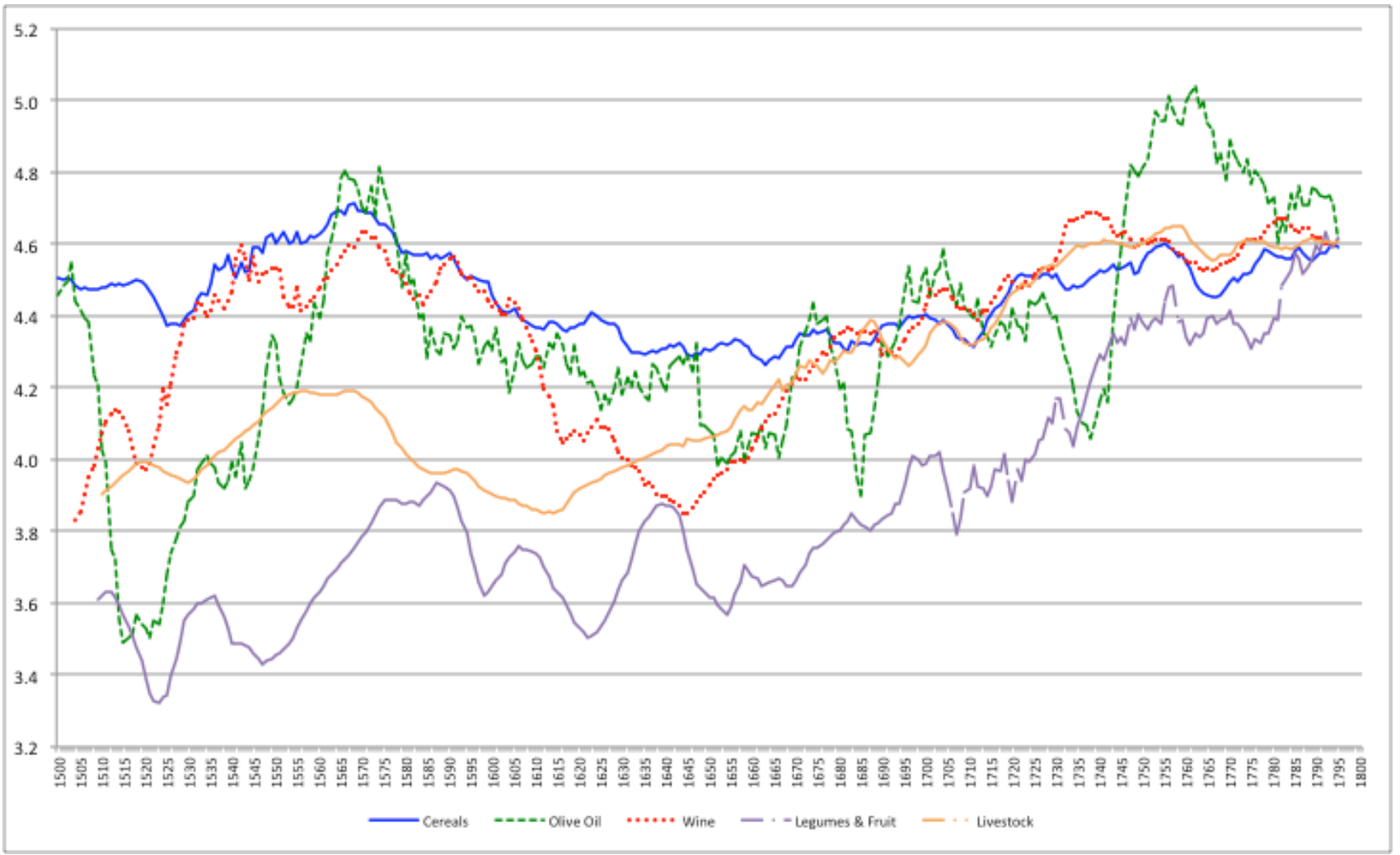

Figure 1. Agricultural Output: Main Components, 1500-1800 (11-year centred moving averages) (1790/99=100), expressed in logs. Source: Appendix A, Table A-1 and see the text.

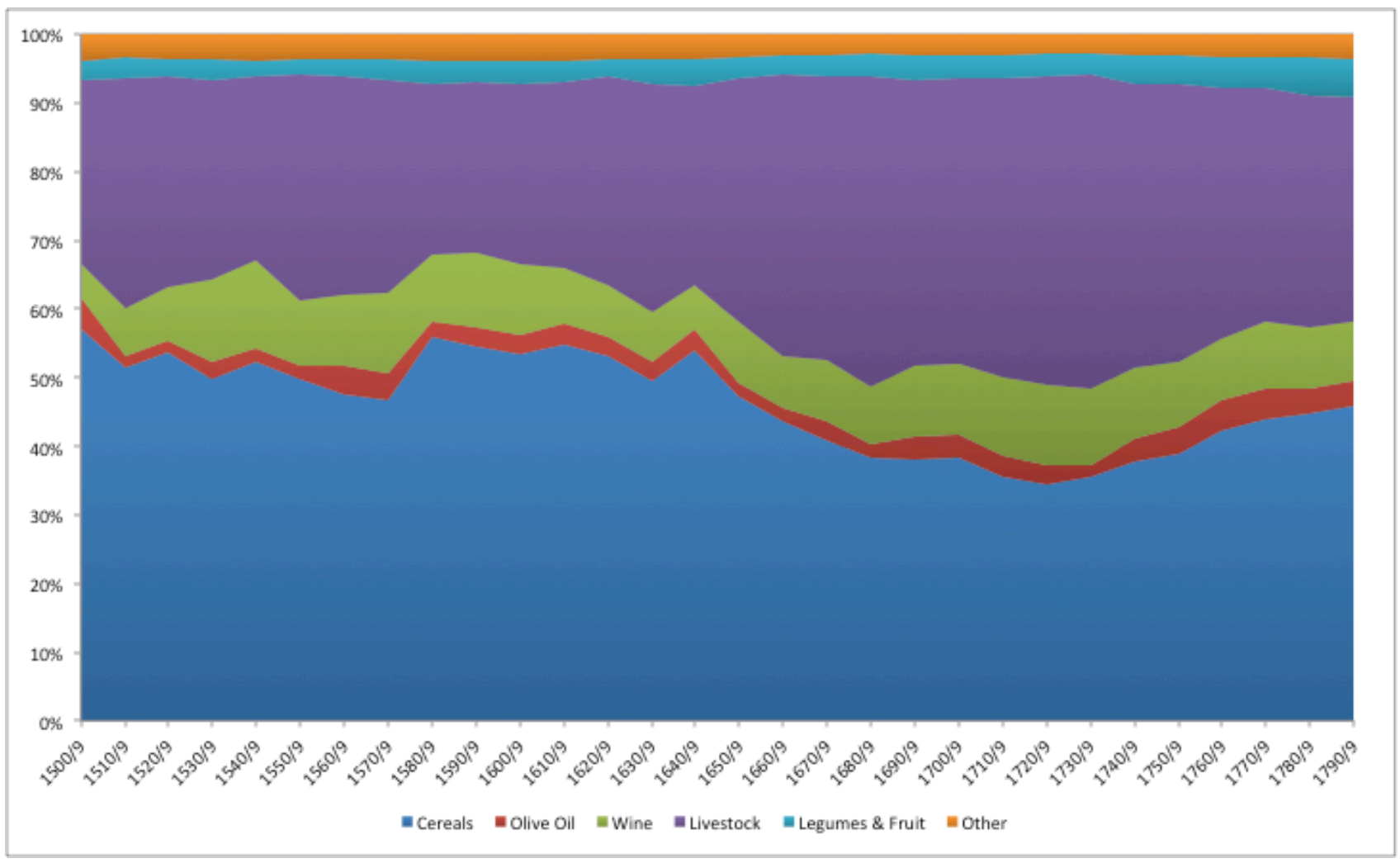

Figure 2. Agricultural Output Composition at current prices, $1500-1800 \%$ (decadal averages). Source: See the text. 


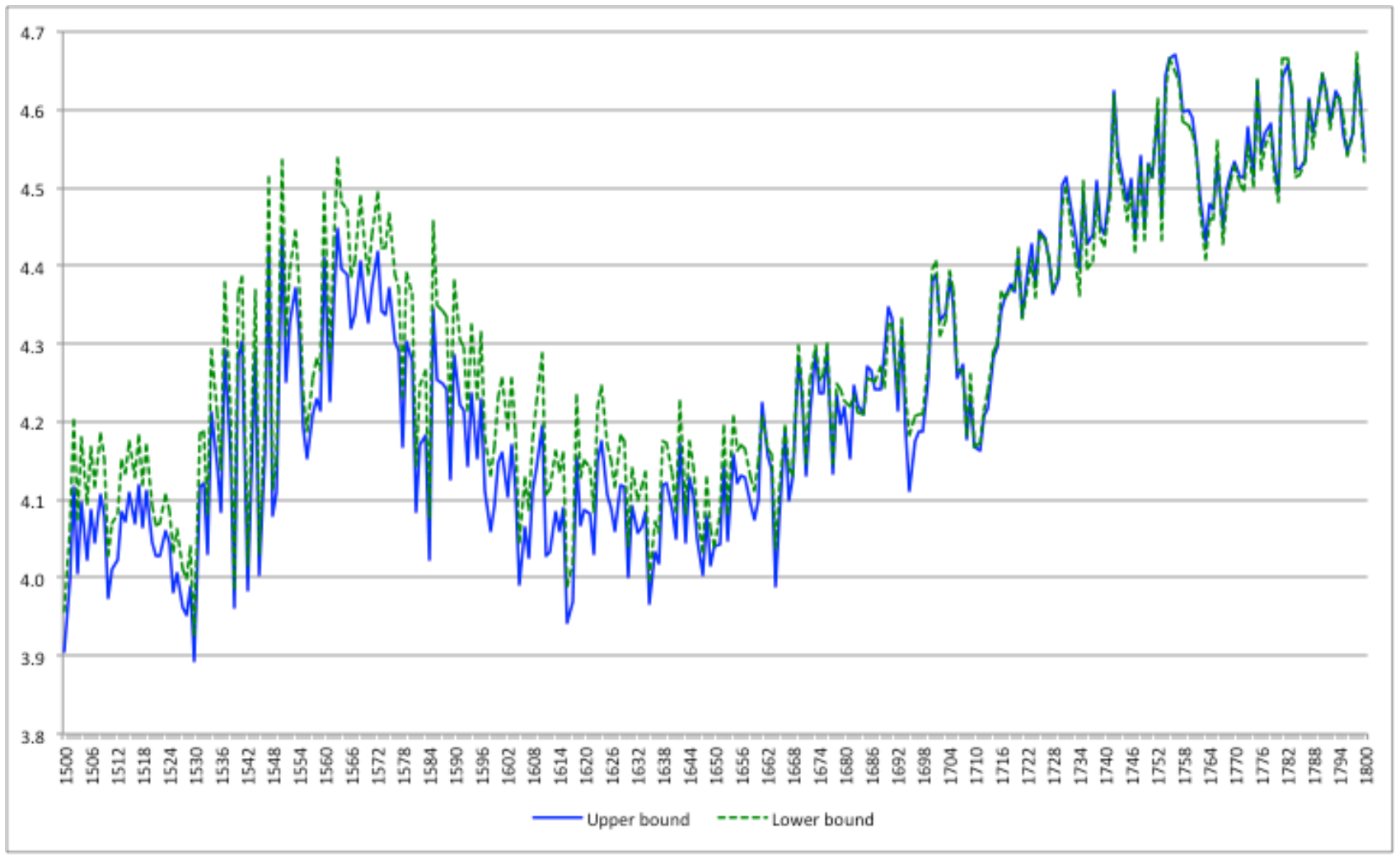

Figure 3. Agricultural Output (upper and lower bound) 1500-1800 (1790/9=100), expressed in logs. Source: Appendix A, Table A-1 and see the text.

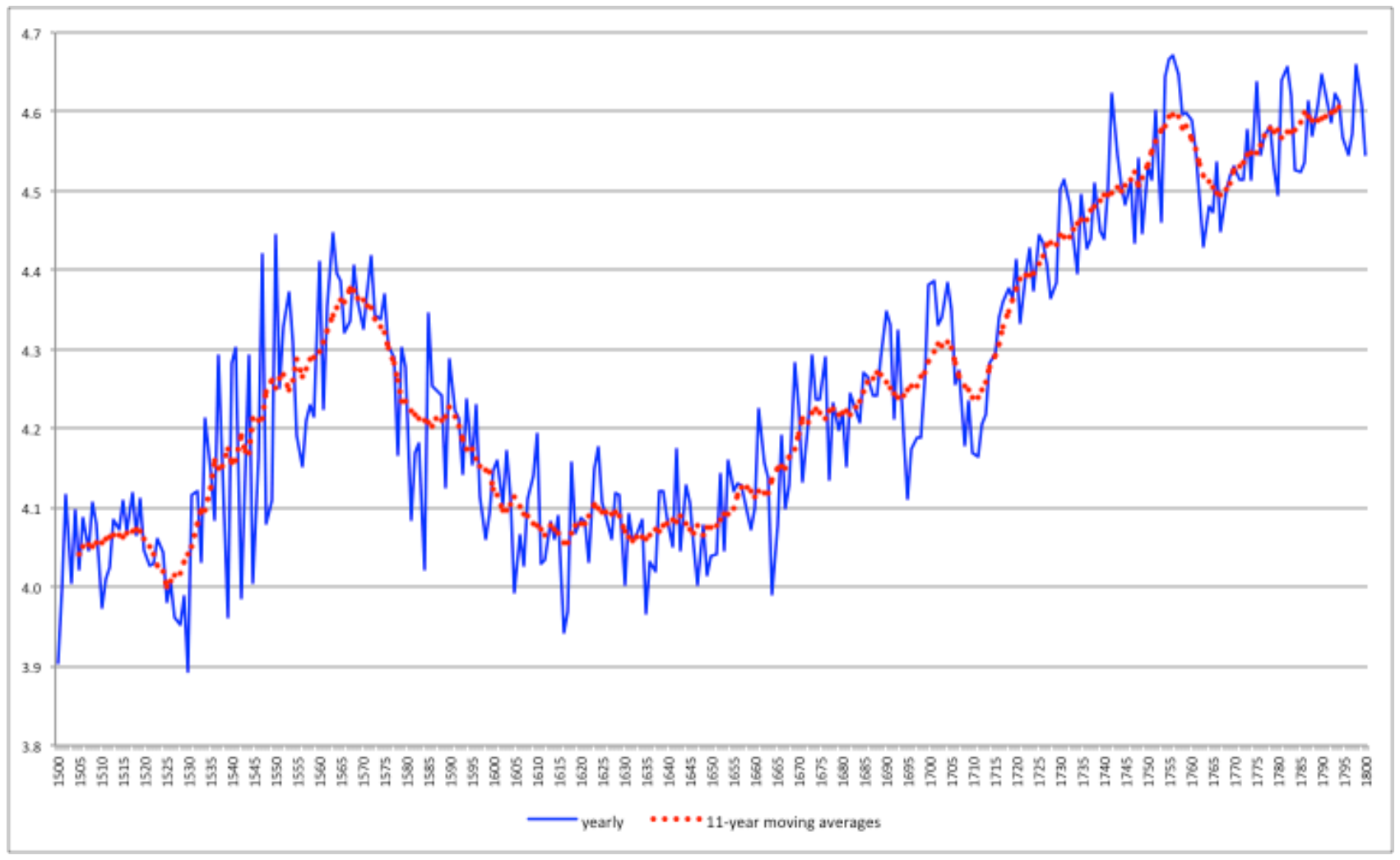

Figure 4. Agricultural Output 1500-1800 (yearly and 11-year centred moving averages), (1790/9=100), expressed in logs. Source: see the text. 


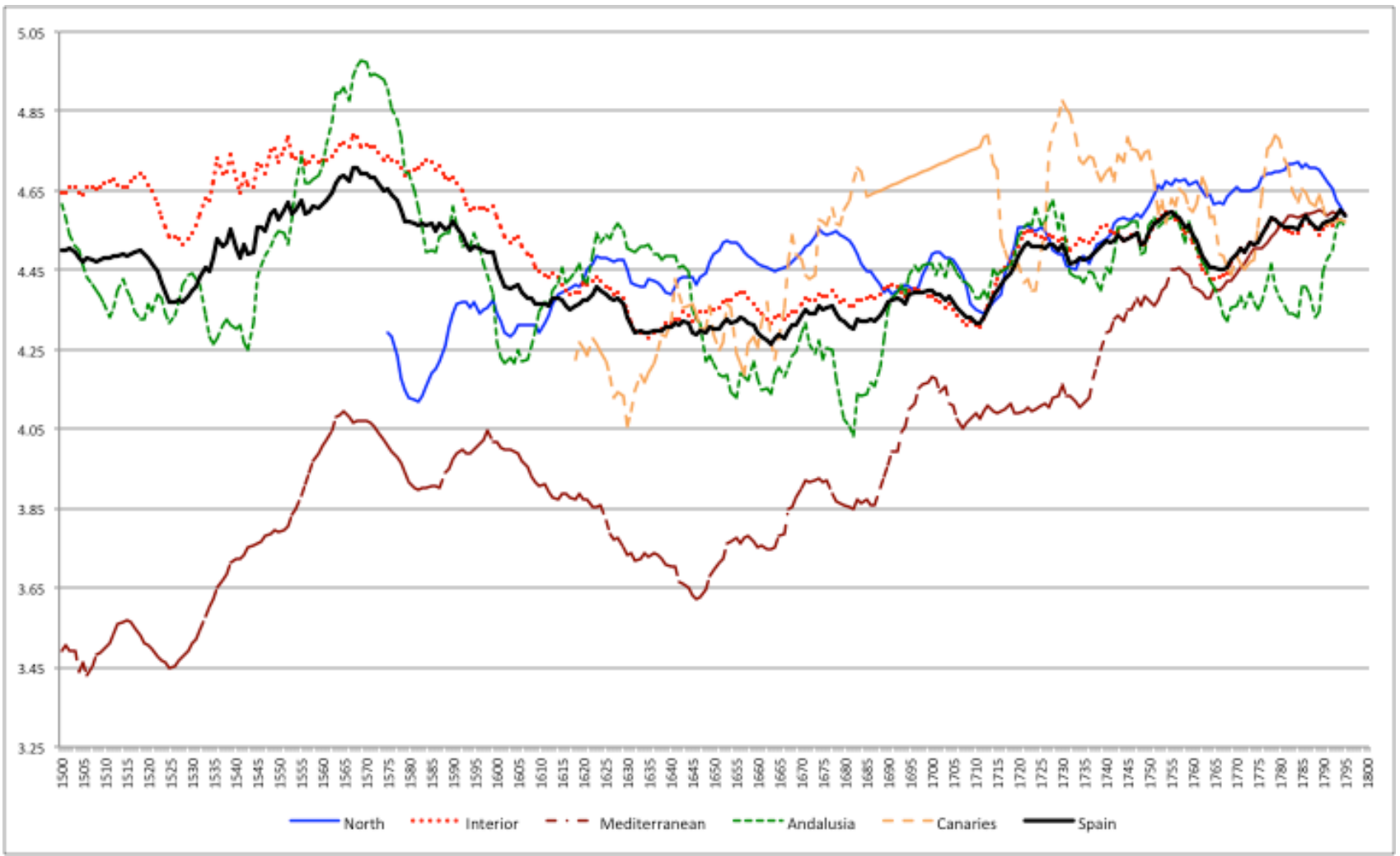

Figure 5. Cereals Output: Main Regions, 1500-1800 (11-year centred moving averages) (1790/99=100), expressed in logs. Source: See the text and Appendix A, Table A-2.

Note: North: Asturias, Galicia, Basque Country, and Navarre; Interior: Extremadura, New and Old Castile, Aragon; Mediterranean: Murcia, Valencia, Catalonia, and Balearic Islands; Andalusia; Canaries.

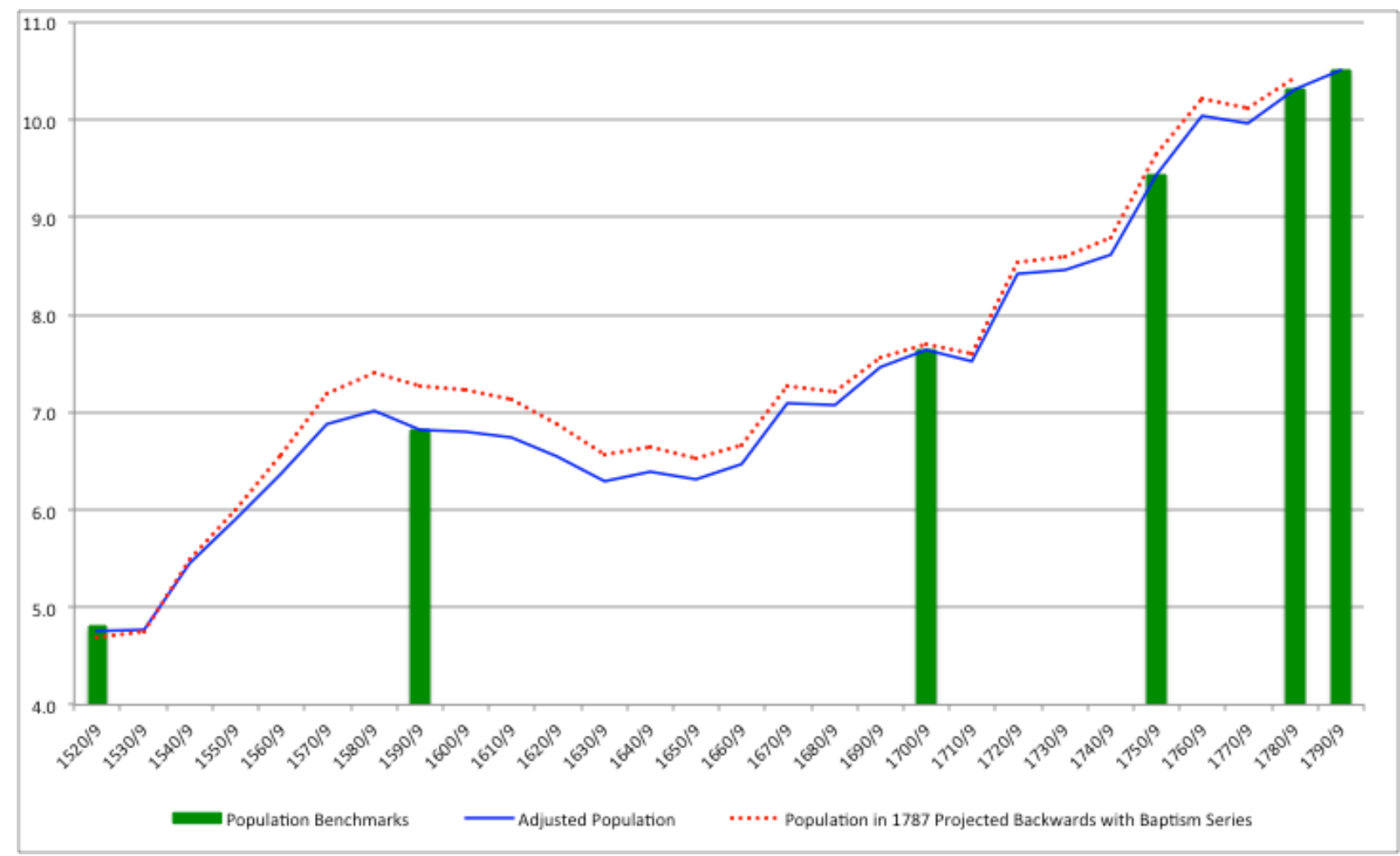

Figure 6. Population Estimates, 1500-1800 (decadal averages) (million)

Sources: Baptisms, Llopis \& Sebastián (2007), Llopis (2004), Reher (unpublished); Benchmarks, see text. Adjusted population, Appendix A, Table A-3 and see the text. 


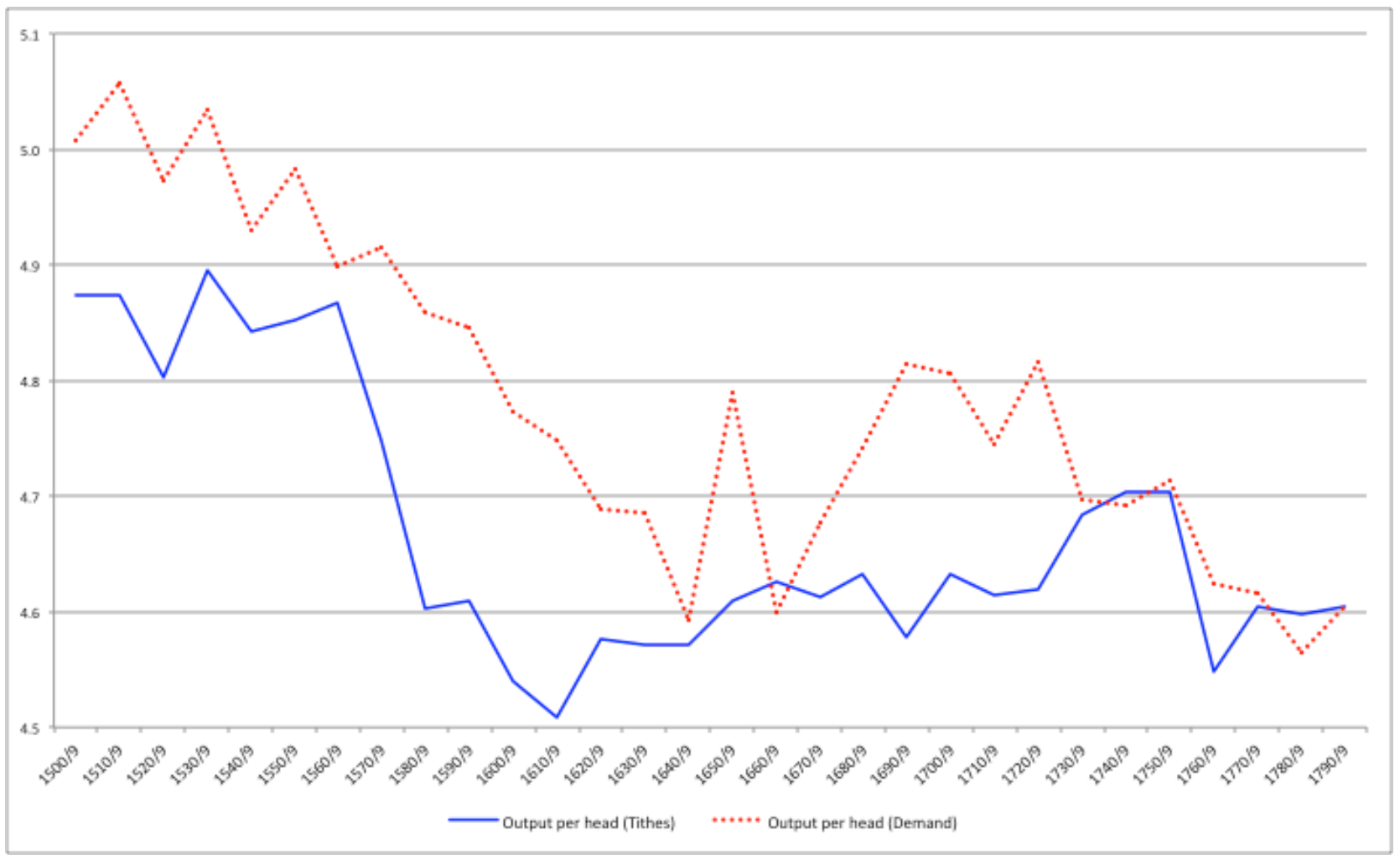

Figure 7. Agricultural output per head (Tithes and Demand approach), 1500-1800 (decadal averages), $(1790 / 99=100)$, expressed in logs. Sources: Appendix A, Table A-3 and see the text.

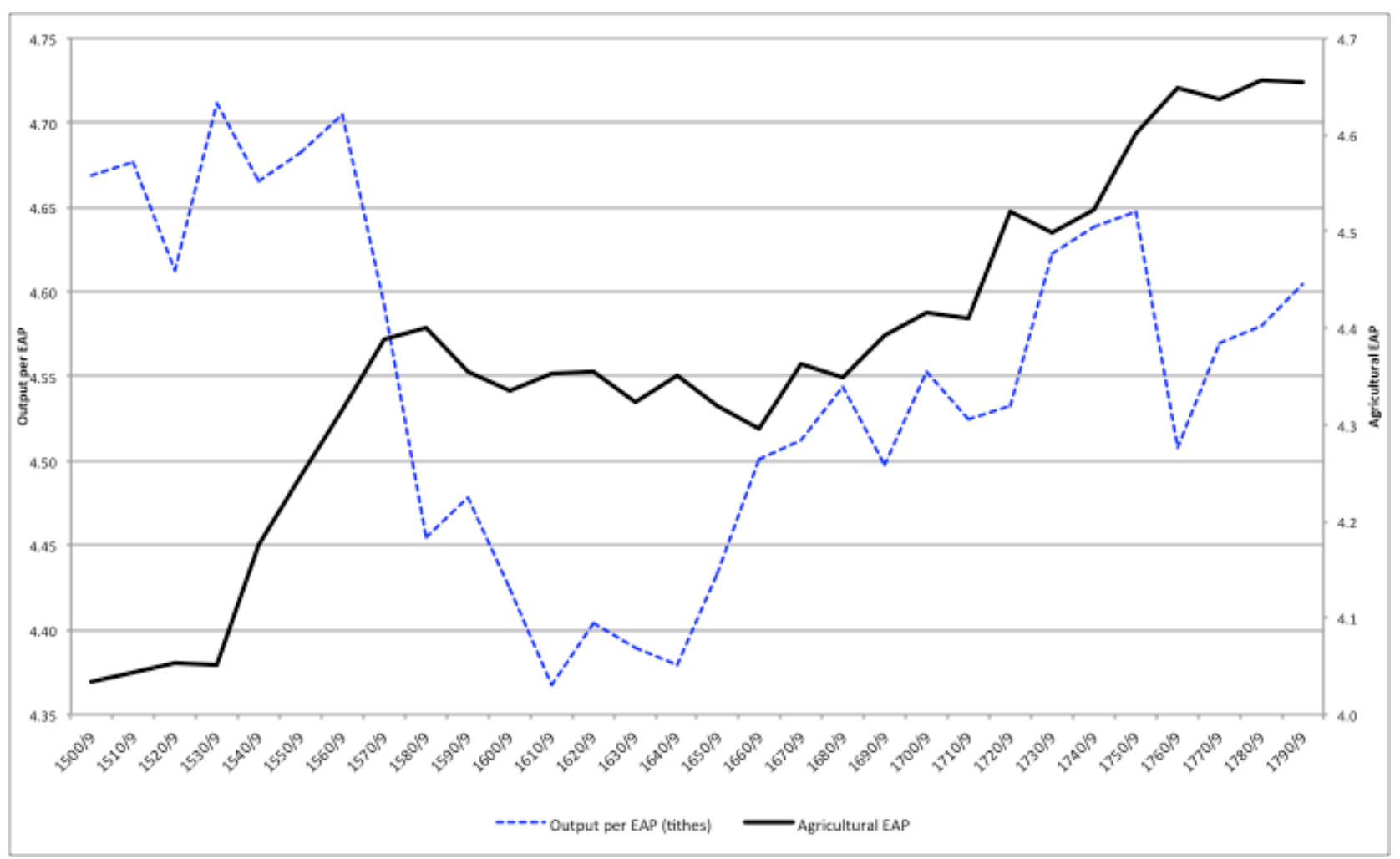

Figure 8. Agricultural output per EAP and economically active population, 1500-1800 (decadal averages) $(1790 / 99=100)$, expressed in logs. Sources: Appendix A, Table A-4 and see the text. 


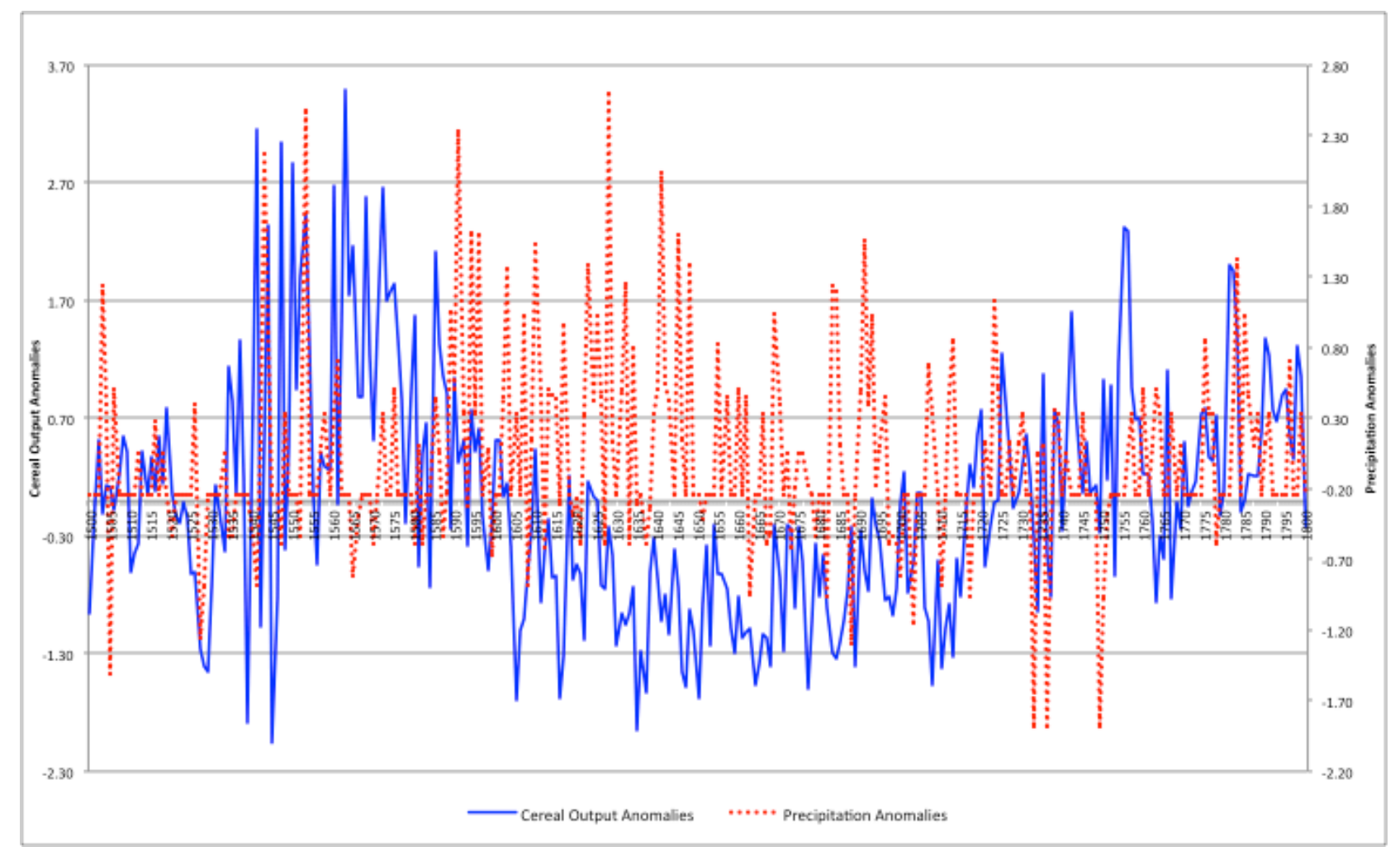

Figure 9. Cereal Output Anomalies and Precipitation Anomalies 1500-1800

Sources: Output, see the text; Precipitation anomalies, Rodrigo et al. (1999). 


\section{Appendix A}

Table A-1

\section{Agricultural Output and Main Crops, 1500-1800 (decadal averages) $(1790 / 99=100)$}

Cereals Olive Oil Wine Legumes \& Fruit Livestock Tot

\begin{tabular}{|c|c|c|c|c|c|c|c|}
\hline & & & & & & (Upper bound) & (Lower bound) \\
\hline $1500 / 9$ & 88.6 & 88.8 & 46.3 & 34.0 & 47.1 & 57.3 & 61.7 \\
\hline $1510 / 9$ & 88.8 & 33.4 & 63.4 & 36.2 & 52.1 & 58.3 & 61.9 \\
\hline $1520 / 9$ & 79.6 & 37.5 & 68.4 & 28.0 & 52.8 & 55.2 & 57.8 \\
\hline $1530 / 9$ & 88.3 & 55.3 & 76.8 & 37.3 & 54.2 & 60.8 & 64.6 \\
\hline $1540 / 9$ & 95.7 & 50.6 & 92.1 & 32.1 & 59.8 & 65.8 & 69.9 \\
\hline $1550 / 9$ & 101.0 & 64.8 & 88.7 & 33.7 & 65.9 & 71.8 & 76.2 \\
\hline $1560 / 9$ & 110.8 & 118.0 & 94.8 & 40.7 & 65.4 & 78.7 & 85.0 \\
\hline $1570 / 9$ & 105.1 & 119.6 & 99.4 & 48.3 & 62.0 & 75.6 & 81.8 \\
\hline $1580 / 9$ & 96.4 & 67.8 & 84.4 & 48.2 & 52.7 & 66.7 & 72.5 \\
\hline $1590 / 9$ & 90.8 & 82.1 & 91.7 & 43.0 & 52.5 & 65.2 & 70.6 \\
\hline $1600 / 9$ & 82.2 & 67.9 & 85.1 & 42.6 & 49.0 & 60.6 & 65.4 \\
\hline $1610 / 9$ & 79.6 & 77.1 & 59.4 & 38.2 & 46.8 & 58.3 & 62.6 \\
\hline $1620 / 9$ & 81.6 & 64.8 & 61.6 & 33.8 & 51.7 & 60.5 & 64.4 \\
\hline $1630 / 9$ & 72.9 & 66.4 & 51.9 & 45.3 & 54.8 & 57.8 & 60.5 \\
\hline $1640 / 9$ & 74.1 & 75.8 & 46.5 & 44.0 & 56.7 & 58.9 & 61.4 \\
\hline $1650 / 9$ & 75.5 & 54.4 & 53.8 & 36.0 & 60.1 & 60.3 & 62.6 \\
\hline $1660 / 9$ & 72.4 & 56.5 & 62.1 & 39.1 & 66.7 & 62.9 & 64.2 \\
\hline $1670 / 9$ & 77.9 & 83.1 & 71.8 & 42.8 & 70.7 & 68.0 & 69.4 \\
\hline $1680 / 9$ & 74.6 & 50.5 & 77.6 & 46.2 & 77.0 & 69.2 & 69.3 \\
\hline $1690 / 9$ & 80.0 & 84.8 & 73.9 & 49.5 & 70.7 & 69.1 & 70.4 \\
\hline $1700 / 9$ & 80.7 & 96.1 & 88.4 & 52.7 & 80.7 & 74.7 & 75.2 \\
\hline $1710 / 9$ & 80.5 & 73.3 & 83.4 & 50.8 & 78.1 & 72.3 & 72.8 \\
\hline $1720 / 9$ & 90.9 & 86.9 & 89.3 & 55.1 & 89.0 & 81.3 & 81.0 \\
\hline $1730 / 9$ & 88.9 & 60.3 & 107.7 & 57.4 & 99.5 & 87.0 & 85.3 \\
\hline $1740 / 9$ & 92.2 & 95.6 & 103.0 & 79.6 & 99.9 & 90.5 & 89.1 \\
\hline $1750 / 9$ & 100.8 & 139.2 & 100.9 & 83.5 & 103.9 & 99.0 & 98.0 \\
\hline $1760 / 9$ & 85.6 & 145.3 & 92.5 & 79.6 & 96.2 & 90.3 & 89.3 \\
\hline $1770 / 9$ & 92.3 & 122.4 & 101.0 & 74.7 & 101.1 & 94.8 & 93.7 \\
\hline $1780 / 9$ & 96.5 & 111.2 & 104.2 & 96.3 & 97.9 & 97.6 & 97.4 \\
\hline $1790 / 9$ & 100.0 & 100.0 & 100.0 & 100.0 & 100.0 & 100.0 & 100.0 \\
\hline
\end{tabular}

Sources: See text. 
Table A-2

\section{Cereal Output: Main Regions, 1500-1800}

(decadal averages) $(1790 / 99=100)$

\begin{tabular}{|c|c|c|c|c|c|}
\hline & North & Interior & Mediterranean & Andalusia & Canarias \\
\hline $1500 / 9$ & & 105.0 & 32.2 & 89.0 & \\
\hline $1510 / 9$ & & 105.7 & 35.7 & 84.6 & \\
\hline $1520 / 9$ & & 94.7 & 31.8 & 76.4 & \\
\hline $1530 / 9$ & & 107.3 & 37.3 & 73.9 & \\
\hline $1540 / 9$ & & 115.4 & 43.0 & 81.2 & \\
\hline $1550 / 9$ & & 114.8 & 47.5 & 114.0 & \\
\hline $1560 / 9$ & & 120.6 & 59.8 & 141.4 & \\
\hline $1570 / 9$ & 74.1 & 113.0 & 55.9 & 142.1 & \\
\hline $1580 / 9$ & 63.9 & 114.2 & 49.7 & 90.4 & \\
\hline $1590 / 9$ & 79.7 & 99.8 & 54.4 & 95.3 & \\
\hline $1600 / 9$ & 74.6 & 93.0 & 54.7 & 69.1 & \\
\hline $1610 / 9$ & 80.9 & 83.5 & 48.4 & 88.9 & 66.1 \\
\hline $1620 / 9$ & 88.9 & 84.2 & 47.1 & 93.1 & 69.6 \\
\hline $1630 / 9$ & 81.8 & 72.3 & 41.7 & 92.3 & 68.6 \\
\hline $1640 / 9$ & 84.1 & 76.1 & 37.9 & 84.8 & 81.9 \\
\hline $1650 / 9$ & 92.1 & 80.7 & 43.9 & 63.7 & 84.5 \\
\hline $1660 / 9$ & 84.8 & 76.2 & 43.3 & 68.5 & 76.0 \\
\hline $1670 / 9$ & 95.8 & 79.9 & 51.1 & 72.3 & 104.4 \\
\hline $1680 / 9$ & 85.3 & 79.2 & 48.0 & 64.0 & 103.0 \\
\hline $1690 / 9$ & 83.1 & 81.1 & 61.1 & 84.2 & 108.0 \\
\hline $1700 / 9$ & 89.3 & 79.5 & 61.7 & 89.7 & 113.2 \\
\hline $1710 / 9$ & 79.4 & 82.3 & 61.2 & 85.0 & 114.9 \\
\hline $1720 / 9$ & 95.0 & 93.4 & 61.6 & 99.3 & 96.5 \\
\hline $1730 / 9$ & 88.8 & 93.7 & 60.4 & 87.0 & 121.1 \\
\hline $1740 / 9$ & 97.7 & 91.4 & 78.6 & 97.3 & 127.8 \\
\hline $1750 / 9$ & 108.1 & 101.7 & 85.9 & 101.6 & 106.4 \\
\hline $1760 / 9$ & 102.8 & 83.2 & 80.2 & 82.8 & 107.8 \\
\hline $1770 / 9$ & 105.4 & 92.5 & 90.8 & 80.5 & 100.2 \\
\hline $1780 / 9$ & 112.5 & 95.6 & 98.5 & 83.6 & 109.7 \\
\hline $1790 / 9$ & 100.0 & 100.0 & 100.0 & 100.0 & 100.0 \\
\hline
\end{tabular}

Note: North: Asturias, Galicia, Basque Country, and Navarre; Interior: Extremadura, New and Old Castile, Aragon; Mediterranean: Murcia, Valencia, Catalonia, and Balearic Islands; Andalusia; Canaries

Sources: See text. 
Table A-3

\section{Agricultural Output per Head, 1500-1800 (decadal averages) $(1790 / 99=100)$}

Tithe approach Demand approach

Population

\begin{tabular}{|c|c|c|c|}
\hline $1500 / 9$ & 130.8 & 149.5 & 43.8 \\
\hline $1510 / 9$ & 130.9 & 157.3 & 44.5 \\
\hline $1520 / 9$ & 121.9 & 144.5 & 45.3 \\
\hline $1530 / 9$ & 133.6 & 153.6 & 45.5 \\
\hline $1540 / 9$ & 126.7 & 138.3 & 51.9 \\
\hline $1550 / 9$ & 128.0 & 145.9 & 56.1 \\
\hline $1560 / 9$ & 129.9 & 134.1 & 60.6 \\
\hline $1570 / 9$ & 115.3 & 136.4 & 65.5 \\
\hline $1580 / 9$ & 99.7 & 128.9 & 66.9 \\
\hline $1590 / 9$ & 100.5 & 127.2 & 64.9 \\
\hline $1600 / 9$ & 93.6 & 118.2 & 64.8 \\
\hline $1610 / 9$ & 90.8 & 115.3 & 64.2 \\
\hline $1620 / 9$ & 97.2 & 108.8 & 62.3 \\
\hline $1630 / 9$ & 96.7 & 108.4 & 59.8 \\
\hline $1640 / 9$ & 96.7 & 98.8 & 60.9 \\
\hline $1650 / 9$ & 100.4 & 120.3 & 60.0 \\
\hline $1660 / 9$ & 102.2 & 99.5 & 61.6 \\
\hline $1670 / 9$ & 100.8 & 107.4 & 67.5 \\
\hline $1680 / 9$ & 102.8 & 114.6 & 67.3 \\
\hline $1690 / 9$ & 97.4 & 123.2 & 71.0 \\
\hline $1700 / 9$ & 102.7 & 122.1 & 72.8 \\
\hline $1710 / 9$ & 101.0 & 114.9 & 71.6 \\
\hline $1720 / 9$ & 101.5 & 123.5 & 80.1 \\
\hline $1730 / 9$ & 108.1 & 109.6 & 80.5 \\
\hline $1740 / 9$ & 110.3 & 109.1 & 82.0 \\
\hline $1750 / 9$ & 110.3 & 111.3 & 89.7 \\
\hline $1760 / 9$ & 94.5 & 101.9 & 95.5 \\
\hline $1770 / 9$ & 99.9 & 101.1 & 94.9 \\
\hline $1780 / 9$ & 99.3 & 96.0 & 98.3 \\
\hline $1790 / 9$ & 100.0 & 100.0 & 100.0 \\
\hline
\end{tabular}

Sources: Output per head derived through tithes (upper bound), see text; Output per head derived through the demand approach, Álvarez-Nogal and Prados de la Escosura (2013), Online Appendix; population, see the text. 
Table A-4

Agricultural Output per Economically Active Population, 1500-1800 (decadal averages) $(1790 / 99=100)$

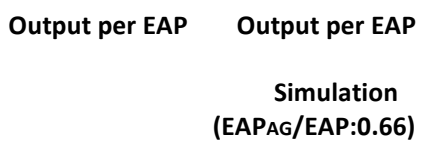

$\begin{array}{rr}106.6 & 130.8 \\ 107.4 & 130.9 \\ 100.7 & 121.9 \\ 111.3 & 133.7 \\ 106.2 & 126.7 \\ 108.1 & 128.0 \\ 110.5 & 129.9 \\ 98.8 & 115.3 \\ 86.0 & 99.7 \\ 88.1 & 101.4 \\ 83.5 & 95.4 \\ 78.8 & 89.5 \\ 81.8 & 92.2 \\ 80.6 & 90.2 \\ 79.8 & 88.7 \\ 84.2 & 93.0 \\ 90.1 & 98.7 \\ 91.1 & 99.1 \\ 94.0 & 101.6 \\ 89.8 & 96.4 \\ 94.9 & 101.2 \\ 92.3 & 97.7 \\ 93.0 & 97.8 \\ 101.8 & 106.2 \\ 103.3 & 107.0 \\ 104.3 & 107.3 \\ 90.8 & 92.7 \\ 96.6 & 97.9 \\ 97.5 & 98.2 \\ 100.0 & 100.0\end{array}$

Sources: See text. 
Appendix C. Sources and procedures

\begin{tabular}{|c|c|c|}
\hline \multicolumn{3}{|c|}{ KINGDOM (Years) } \\
\hline \multicolumn{3}{|c|}{ MAIN REGION (Years) } \\
\hline \multicolumn{3}{|c|}{ Sub Region (Years) } \\
\hline Years & Source & Location \\
\hline
\end{tabular}

\section{CEREALS}

\begin{tabular}{|l|l|l|}
\hline \multicolumn{2}{|c|}{ KINGDOM OF ARAGON (1466-1800) } \\
\hline \multicolumn{3}{|c|}{ ARAGON (1610-1800) } \\
\hline $1610-1800$ & Latorre Ciria (2007) & \multicolumn{2}{|c|}{ BALEARIC ISLANDS (1466-1800) } \\
\hline \multicolumn{3}{|l|}{ CATALONIA (1508-1800) } \\
\hline $1466-1800$ & Vidal (1978) & Palaudaries \\
\hline \multicolumn{3}{|l|}{} \\
\hline $1508-1601$ & Dantí I Riu (1987) & Palaudaries and Sentmena \\
\hline $1602-1658$ & $\begin{array}{l}\text { Dantí I Riu (1987) } \\
\text { Serra ( 1988) }\end{array}$ & Sentmenat \\
\hline $1658-1729$ & Serra i Puig (1978) & Sans-Mataró \\
\hline $1730-1756$ & Badosa i Coll (1978) & Mataró \\
\hline $1756-1800$ & Fradera ( 1978) & \\
\hline & \multicolumn{1}{|c|}{ VALENCIA (1501-1800) } \\
\hline $1501-1565$ & Casey (1979) & \\
\hline $1566-1700$ & $\begin{array}{l}\text { Casey (1979) } \\
\text { Ardit Lucas (1987) } \\
\text { Palop Ramos (1982) }\end{array}$ & \\
\hline $1701-1800$ & $\begin{array}{l}\text { Ardit Lucas (1987) } \\
\text { Palop Ramos (1982) }\end{array}$ \\
\hline
\end{tabular}

\section{NAVARRE (1569-1634)}

1569-1634 $\quad$ Belascoain Cemborain (2011)

\begin{tabular}{|c|c|c|}
\hline \multicolumn{3}{|c|}{ KINGDOM OF CASTILE (1408-1800) } \\
\hline \multicolumn{3}{|c|}{ ANDALUSIA (1402-1800) } \\
\hline \multicolumn{3}{|r|}{ Seville (1408-1800) } \\
\hline $1408-1503$ & Ladero Quesada (1979) & Archbishopric of Seville \\
\hline 1469-1503 & Ladero Quesada (1979) & Seville, Carmona, Jerez and Niebla \\
\hline $1515-1579$ & Ponsot $(1986)^{36}$ & $\begin{array}{l}\text { Albaida } \\
\text { Alcala del Rio, Cazalla de la Sierra, Coria, Marchena and Mairena del } \\
\text { Alcor, los Molares, la Campana, Moron, Osuna and } \\
\text { Utrera }\end{array}$ \\
\hline $1580-1605$ & Ponsot (1986) & $\begin{array}{l}\text { Albaida, Alcala del Rio, Cazalla de la Sierra, Coria, Marchena, Mairena } \\
\text { del Alcor, Los Molares, La Campana, Moron, Osuna, Utrera, Seville } \\
\text { and Carmona }\end{array}$ \\
\hline
\end{tabular}

\footnotetext{
${ }^{36}$ We used series for Cadiz and Huelva from Ladero Quesada (1979) that overlap with the Seville series to splicing the pre-1503 and post-1515 series.
} 


\begin{tabular}{|c|c|c|}
\hline $1606-1800$ & Ponsot (1986) & Montemayor \\
\hline \multicolumn{3}{|r|}{ Cadiz (1493-1800) } \\
\hline $1493-1800$ & Ponsot (1986 & Conil, Jerez, Chiclana, Vejer, Medina Sidonia and Trebujena \\
\hline \multicolumn{3}{|r|}{ Huelva (1451-1800) } \\
\hline $1451-1490$ & González Gomez (1980) & Trigueros \\
\hline $1490-1605$ & Ponsot (1986) & $\begin{array}{l}\text { Niebla, Aljaraque, Almonte, Hinojosos, Moguer, Aracena and la } \\
\text { Palma }\end{array}$ \\
\hline $1606-1800$ & Ponsot (1986) & Niebla, Aljaraque, Almonte, Hinojosos \\
\hline \multicolumn{3}{|r|}{ Cordoba $(1580-1800)$} \\
\hline $1580-1800$ & Ponsot (1986) & $\begin{array}{l}\text { Baena, Bujalance, Cabra, Castro y Espejo, Espiel, Fernan Nuñez, } \\
\text { Montoro, Palma del Rio, Posadas, la Rambla, Santaella and Cordoba }\end{array}$ \\
\hline \multicolumn{3}{|r|}{ Granada (1690-1800) } \\
\hline $1690-1800$ & Garzon Pareja $(1974,1982)$ & \\
\hline \multicolumn{3}{|r|}{ Malaga (1555-1800) } \\
\hline $1555-1800$ & Benitez Sanchez-Blanco (1982) & Cartama, Borge, Setenil, Antequera, Marbella and Casares. \\
\hline \multicolumn{3}{|c|}{ EXTREMADURA (1500-1788) } \\
\hline $1500-1599$ & Pereira Iglesias $(1990)^{37}$ & Caceres \\
\hline $1739-1744$ & Llopis Agelán (1979) & Cortijo de San Isidro \\
\hline $1745-1781$ & Llopis Agelán (1979) & $\begin{array}{l}\text { Casa de Madrigalejo, Casa de la Burquilla, Casa de la Vega, and Casa } \\
\text { del Rincon }\end{array}$ \\
\hline $1782-1788$ & Llopis Agelán (1979) & Casa de la Vega and Casa del Rincon \\
\hline $1744-1764$ & Rodriguez Cancho et al. (2004) & Plasencia \\
\hline $1797-1800$ & Rodriguez Cancho et al. (2004) & Plasencia \\
\hline \multicolumn{3}{|c|}{ CANARY ISLANDS(1613-1800) } \\
\hline $1613-1800$ & Macias Hernandez (1984) & $\begin{array}{l}\text { Arucas, Teror, Telde, Matanza, Realejos, Icod, Arico, Tirajana, and } \\
\text { Fuerteventura }\end{array}$ \\
\hline \multicolumn{3}{|r|}{ MURCIA (1580-1800) } \\
\hline $1580-1800$ & Lemeunier (1982) & \\
\hline \multicolumn{3}{|c|}{ NEW CASTILE (1463-1800) } \\
\hline $1463-1699$ & $\begin{array}{l}\text { López-Salazar Perez and Martín } \\
\text { Galán (1981) }\end{array}$ & $\begin{array}{l}\text { Alcala de Henares, Alcaraz, Alcolea de Torote, Brihuega, Buitrago, } \\
\text { Calatrava, Canales, Escalona, Guadalajara, La Guardia, Hita, Illescas, } \\
\text { Madrid, Montalban, Ocaña, Rodillas, Santa Olalla y Maqueda, } \\
\text { Talamanca, Talavera de la Reina, La Puebla de Alcocer, Zorita de los } \\
\text { Canes, and Almoguera }\end{array}$ \\
\hline $1700-1800$ & Santiago-Caballero (2014) & Guadalajara \\
\hline \multicolumn{3}{|c|}{ OLD CASTILE (1402-1800) } \\
\hline \multicolumn{3}{|r|}{ Burgos (1402-1800) } \\
\hline $1402-1520$ & Casado Alonso (1991) & \\
\hline $1590-1800$ & $\begin{array}{l}\text { Hernández García and Pérez } \\
\text { Romero }(2008)^{38}\end{array}$ & \\
\hline \multicolumn{3}{|r|}{ La Rioja $(1550-1800)$} \\
\hline $1550-1800$ & $\begin{array}{l}\text { Ibañez Rodriguez and Alonso } \\
\text { Castrobiejo (1996) }\end{array}$ & \\
\hline \multicolumn{3}{|r|}{ Santander (1607-1800) } \\
\hline $1607-1800$ & Lanza García (1991) & Rozas, Piasca, San Mames de Meruelo, Abionzo, and Gajano \\
\hline
\end{tabular}

${ }^{37}$ Tithes paid in cash that were deflated.

${ }^{38}$ Tithes paid in cash that were deflated. 


\begin{tabular}{|l|l|l|}
\hline \multicolumn{1}{|c|}{ Leon (1569-1800) } \\
\hline $1569-1800$ & Sebastian Amarilla (1992) & Monastery of Sandoval \\
\hline \multicolumn{3}{|c|}{ Palencia and Valladolid (1550-1800) } \\
\hline $1550-1800$ & García and Pérez Romero (2008) $^{39}$ & \\
\hline \multicolumn{3}{|c|}{ Segovia (1550-1800) } \\
\hline $1550-1800$ & García and Pérez Romero (2008) $^{40}$ & Soria (1550-1800) \\
\hline \multicolumn{3}{|c|}{ BASQUE PROVINCES (1537-1800) } \\
\hline $1550-1800$ & García and Pérez Romero (2008) & \\
\hline \multicolumn{3}{|c|}{ (1523-1800) } \\
\hline $1523-1800$ & Álvarez Vázquez (1984) & \\
\hline \multicolumn{3}{|c|}{ GALICIA (1594-1800) } \\
\hline $1537-1800$ & $\begin{array}{l}\text { Bilbao Bilbao and Fernandez de } \\
\text { Pinedo (1984) }\end{array}$ \\
\hline
\end{tabular}

\section{WINE}

\begin{tabular}{|l|l|l|}
\hline \multicolumn{2}{|c|}{ KINGDOM OF ARAGON (1502-1800) } \\
\hline \multicolumn{2}{|c|}{ ARAGON (1502-1600) } \\
\hline $1502-1600$ & Latorre Ciria (1989) & \multicolumn{2}{|c|}{ Liesa, Floren, and Huesca } \\
\hline \multicolumn{2}{|l|}{ CATALONIA(1666-1800) } \\
\hline $1666-1712$ & Serra i Puig (1978) & Martorelles \\
\hline $1713-1725$ & Vicedo i Rius (1982) & Lleida \\
\hline $1726-1781$ & Vicedo i Rius (1982) & Lleida \\
& Badosa i Coll (1978) & Gracia-Sant Geivasi \\
& Fradera (1978) & Mataró \\
\hline $1782-1800$ & Vicedo i Rius (1982) & Lleida \\
& Fradera (1978) & Mataró \\
\hline
\end{tabular}

\section{NAVARRE (1569-1625)}

1569-1625 $\quad$ Belascoain Cemborain (2011).

\begin{tabular}{|c|c|c|}
\hline \multicolumn{3}{|c|}{ KINGDOM OF CASTILE (1490-1800) } \\
\hline \multicolumn{3}{|c|}{ ANDALUSIA (1490-1800) } \\
\hline \multicolumn{3}{|c|}{ Seville $(1490-1800)^{42}$} \\
\hline $1490-1601$ & Ponsot (1986) & $\begin{array}{l}\text { Albaida, Alcala del Rio, Cazalla de la Sierra, Coria, El Copero, Lebrija, } \\
\text { Marchena, Mairena del Alcor, Moron, and Utrera }\end{array}$ \\
\hline $1602-1641$ & Ponsot (1986) & Montemayor \\
\hline $1642-1678$ & Ponsot (1986) & $\begin{array}{l}\text { Alcala del Rio, Cazalla de la Sierra, Lebrija, Marchena, Montemayor, } \\
\text { and Osuna }\end{array}$ \\
\hline $1679-1800$ & Ponsot (1986) & Alcala del Rio, Cazalla de la Sierra, Lebrija, Marchena, and Osuna \\
\hline \multicolumn{3}{|r|}{ Cadiz $(1494-1800)^{43}$} \\
\hline
\end{tabular}

${ }^{39}$ Decadal estimates.

${ }^{40}$ Decadal estimates.

${ }^{41}$ Decadal estimates.

${ }^{42}$ Series were in cash and were deflated using the prices in Ponsot (1986). 


\begin{tabular}{|c|c|c|}
\hline $1494-1800$ & Ponsot (1986) & Jerez and Chiclana \\
\hline \multicolumn{3}{|r|}{ Huelva $(1579-1800)^{44}$} \\
\hline $1579-1641$ & Ponsot (1986) & La Palma \\
\hline $1642-1800$ & Ponsot (1986) & La Palma and Almonte \\
\hline \multicolumn{3}{|c|}{ Cordoba $(1580-1800)^{45}$} \\
\hline $1580-1800$ & Ponsot (1986) & $\begin{array}{l}\text { Baena, Cabra, Castro y Espejo, Espiel, Montoro, Posadas, and La } \\
\text { Rambla }\end{array}$ \\
\hline \multicolumn{3}{|c|}{ OLD CASTILE (1550-1800) } \\
\hline \multicolumn{3}{|r|}{ Burgos (1550-1800) } \\
\hline $1550-1800$ & $\begin{array}{l}\text { Ibañez Rodriguez and Alonso } \\
\text { Castrobiejo (1996) }\end{array}$ & \\
\hline \multicolumn{3}{|c|}{ Santander (1624-1800) } \\
\hline $1624-1800$ & Lanza García (1991) & Piasca, Santiago de Heras, Valle de Ruesga, Gajano, and Rubayo \\
\hline \multicolumn{3}{|r|}{ Segovia $(1610-1800)$} \\
\hline $1610-1800$ & García Sanz (1977) & \\
\hline \multicolumn{3}{|c|}{ BASQUE PROVINCES (1537-1800) } \\
\hline $1537-1800$ & $\begin{array}{l}\text { Bilbao \& Fernandez de Pinedo } \\
\text { (1984) }\end{array}$ & \\
\hline
\end{tabular}

OLIVE OIL

\begin{tabular}{|l|l|l|}
\hline \multicolumn{2}{|c|}{ KINGDOM OF ARAGON (1570-1800) } \\
\hline \multicolumn{2}{|c|}{ ARAGON (1750-1800) } \\
\hline $1750-1800$ & Daviu y Pons (1978) & \multicolumn{1}{|c|}{ Majorca } \\
\hline \multicolumn{3}{|c|}{ BALEARIC ISLANDS (1750-1800) } \\
\hline $1750-1800$ & Daviu y Pons (1978) & \multicolumn{2}{|c|}{ Majorca } \\
\hline \multicolumn{3}{|c|}{ CATALONIA (1716-1769) } \\
\hline $1716-1751$ & Serra i Puig (1978) & Santa Creu dUlorda \\
\hline $1752-1769$ & $\begin{array}{l}\text { Serra i Puig (1978) } \\
\text { Badosa i Coll (1978) }\end{array}$ & $\begin{array}{l}\text { Santa Creu dUlorda } \\
\text { Gracia-Sant Gervasi }\end{array}$ \\
\hline
\end{tabular}

\begin{tabular}{|c|c|c|}
\hline \multicolumn{3}{|c|}{ KINGDOM OF CASTILE (1428-1800) } \\
\hline \multicolumn{3}{|c|}{ ANDALUSIA (1428-1800) } \\
\hline \multicolumn{3}{|r|}{ Seville (1428-1800) } \\
\hline $1428-1510$ & González Arce (2015) ${ }^{46}$ & Aljarafe Shire \\
\hline $1494-1560$ & Ponsot (1986) & $\begin{array}{l}\text { Albaida, Alcala de Guadaira, Santa Maria de Carmona, Cazalla de la } \\
\text { Sierra, El Coronil, Lebrija, Marchena, Mairena del Alcor, Moron, } \\
\text { Osuna, and Utrera }\end{array}$ \\
\hline 1561-1567 & Ponsot (1986) & Santa Maria de Carmona and El Coronil \\
\hline $1568-1598$ & Ponsot (1986) & $\begin{array}{l}\text { Albaida, Alcala de Guadaira, Santa Maria de Carmona, Cazalla de la } \\
\text { Sierra, El Coronil, Lebrija, Marchena, Mairena del Alcor, Moron, } \\
\text { Osuna, and Utrera }\end{array}$ \\
\hline
\end{tabular}

\footnotetext{
${ }^{43}$ Series were obtained by deflating tithes in cash paid with prices in Ponsot (1986).

${ }^{44}$ Series were obtained by deflating tithes in cash paid with prices in Ponsot (1986).

${ }^{45}$ Series were obtained by deflating tithes in cash paid with prices in Ponsot (1986).

${ }^{46}$ Combine both tithes in quantity and value. For those years for which we only had values, we deflated them with the average price of olive oil between 1478 and 1490, as suggested by the author. We carried out a robustness check using those years when we had both quantity and value. The results indicate that the use of the average price for the period $1478-1490$ is a valid way of estimating the quantity produced from the value taxed.
} 


\begin{tabular}{|c|c|c|}
\hline $1599-1641$ & Ponsot (1986) & Santa Maria de Carmona, and El Coronil \\
\hline $1642-1769$ & Ponsot (1986) & Santa Maria de Carmona, Marchena, and Osuna \\
\hline $1770-1800$ & Ponsot (1986) & Cazalla de la Sierra, Lebrija, Marchena, and Osuna \\
\hline \multicolumn{3}{|r|}{ Huelva $(1494-1800)^{47}$} \\
\hline $1494-1608$ & Ponsot (1986) & Moguer, Aracena and, la Palma \\
\hline $1609-1641$ & Ponsot (1986) & Hinojosos \\
\hline $1642-1800$ & Ponsot (1986) & Moguer and la Palma \\
\hline \multicolumn{3}{|c|}{ Cordoba $(1581-1800)^{48}$} \\
\hline $1581-1800$ & Ponsot (1986) & $\begin{array}{l}\text { Baena, Bulajance, Cabra, Castro y Espejo, Fernan Nuñez, Montoro, } \\
\text { Palma del Rio, Posadas, La Rambla, and Santaella }\end{array}$ \\
\hline \multicolumn{3}{|r|}{ EXTREMADURA (1697-1788) } \\
\hline 1697-1788 & Llopis Agelan (1979) & Casa del Rincon \\
\hline
\end{tabular}

\section{VEGETABLES AND FRUITS}

\begin{tabular}{|l|l|l|}
\hline \multicolumn{3}{|c|}{ KINGDOM OF ARAGON (1649-1800) } \\
\hline \multicolumn{2}{|c|}{ BALEARIC ISLANDS (1649-1800) } \\
\hline $1649-1800$ & \multicolumn{1}{|c|}{ Vidal (1978) } & Majorca \\
\hline \multicolumn{3}{|c|}{ CATALONIA (1658-1800) } \\
\hline $1658-1670$ & Serra i Puig (1978) & Martorelles \\
\hline $1671-1715$ & Serra i Puig (1978) & Martorelles and Sentmenat \\
\hline $1716-1729$ & $\begin{array}{l}\text { Serra i Puig (1978) } \\
\text { Badosa i Coll (1978) }\end{array}$ & $\begin{array}{l}\text { Sentmenat and Badosa } \\
\text { Sants/I'Hospitalet }\end{array}$ \\
\hline $1730-1760$ & Badosa i Coll (1978) & Sants/I'Hospitalet and Gracia-Sant Geivasi \\
\hline $1761-1800$ & Badosa i Coll (1978) & Sants/I'Hospitalet \\
\hline $\begin{array}{l}\text { Valencia } \\
(1499-1700)\end{array}$ & & \\
\hline $\begin{array}{l}1553-1700 \\
\text { (Fruits) }\end{array}$ & Casey (1979) & \\
\hline $\begin{array}{l}1499-1602 \\
\text { (Vegetables) }\end{array}$ & Salvador Esteban (2004) & \\
\hline
\end{tabular}

\section{LIVESTOCK PRODUCE}

\begin{tabular}{|l|l|l|}
\hline \multicolumn{2}{|c|}{ KINGDOM OF ARAGON (1501-1800) } \\
\hline \multicolumn{2}{|c|}{ ARAGON (1610-1800) } \\
\hline $1610-1800$ & Latorre Ciria (2007) & \\
\hline \multicolumn{3}{|l|}{} \\
\hline $1501-1565$ & Casey (1979) & VALENCIA (1501-1800) \\
\hline $1566-1700$ & $\begin{array}{l}\text { Casey (1979) } \\
\text { Ardit Lucas (1987) }\end{array}$ & \\
\hline $1701-1800$ & Ardit Lucas (1987) & \\
\hline
\end{tabular}

\footnotetext{
${ }^{47}$ The series in cash were deflated d with prices in Ponsot (1986).

${ }^{48}$ Series in cash deflated with prices in Ponsot (1986).
} 


\begin{tabular}{|l|l|l|}
\hline \multicolumn{2}{|c|}{ KINGDOM OF CASTILE (1500-1800) } \\
\hline \multicolumn{3}{|c|}{ MURCIA (1591-1800) } \\
\hline $1591-1800$ & Pérez Picazo and Lemeunier (1984) & \\
\hline \multicolumn{3}{|c|}{ EXTREMADURA (1500-1800) } \\
\hline $1500-1599$ & Pereira Iglesias (1990) & Monastery of Guadalupe \\
\hline $1692-1800$ & $\begin{array}{l}\text { Llopis Agelán (1979) } \\
\text { Melón Jiménez (1998) }\end{array}$ & OLD CASTILE (1610-1800) \\
\hline \multicolumn{3}{|l|}{ Segovia (1610-1800) } \\
\hline \multicolumn{3}{|l|}{} \\
\hline $1610-1800$ & Garcia Sanz (1977) & Soria (1682-1800) \\
\hline & & \\
\hline $1682-1800$ & Andrés Gallego (1973) &
\end{tabular}

